\title{
The ammonoids from the Grès du Kahla supérieur of Timimoun (Middle-early Late Tournaisian; Gourara, Algeria)
}

\author{
Dieter Korn $^{*}, 1$, Volker Ebbighausen ${ }^{2}$ and Jürgen Bockwinkel ${ }^{3}$ \\ ${ }^{1}$ Museum für Naturkunde Berlin, Invalidenstraße 43, 10115 Berlin, Germany. E-mail: dieter.korn@mfn-berlin.de \\ ${ }^{2}$ Engstenberger Höhe 12, 51519 Odenthal, Germany. E-mail: Volker@vxr.de \\ ${ }^{3}$ Dechant-Feinstraße 22, 51375 Leverkusen, Germany. E-mail: jbockwinkel@t-online.de
}

\begin{abstract}
Received 18 June 2009

Accepted 7 August 2009

Published 19 February 2010

\section{Key Words}

\section{Ammonoidea}

Mississippian

Carboniferous

The ammonoids from two very prolific horizons in the upper Kahla Sandstone (Tournaisian, Early Carboniferous) of Timimoun (Gourara, Algeria) are described monographically. Nine new ammonoid species are introduced: Imitoceras altilobatum n. sp., Triimitoceras amplisellatum n. sp., Kazakhstania inequalis n. sp., Acrocanites imperfectus n. sp., Xinjiangites scalaris n. sp., and Becanites canalifer n. sp. from the North African Kazakhstania-Acrocanites Assemblage as well as Acrocanites recurvus n. sp., Becanites singularis n. sp., and Becanites inflateralis n. sp. from the Pericyclus-Progoniatites Assemblage. The first of these is one of the most diverse ammonoid faunas known from this time interval.
\end{abstract}

North Africa

taxonomy

\section{Introduction}

Middle and early Late Tournaisian ammonoids belong to the poorest known representatives in the Palaeozoic history of the clade. In some regions with otherwise rich Early Carboniferous ammonoid records, this time interval is represented by black shales and cherts, which are extremely poor in macrofossils. Therefore, ammonoid faunas from this interval are reported from only a few regions.

Missouri - The Chouteau Limestone and Northview Shale yielded ammonoid faunas (Smith 1903; Miller \& Collinson 1951), which probably belong in the Middle Tournaisian or earliest Late Tournaisian. From these two formations, the genera Imitoceras, Masonoceras, Gattendorfia (?), Prodromites, Xinjiangites, Goniocyclus (restricted to the Chouteau Limestone), and Protocanites are known.

Indiana - The Rockford Limestone was very productive for ammonoid faunas (Hall 1860; Miller 1891; Gutschick \& Treckman 1957); they most likely come from the earliest Late Tournaisian. The fauna is composed of the genera Imitoceras, Gattendorfia,
Prodromites, Muensteroceras, and Protocanites. Its similarity to the fauna of the Chouteau Limestone led Miller \& Collinson (1951) to assume that the two are time equivalents.

Kentucky - Early, middle, and late Osagean ammonoid assemblages (Work \& Mason 2003, 2004, 2005) show a succession similar to the occurrences in Algeria. The Cave Run Lake fauna (Nancy Member of the Borden Formation; early Osagean) with Kazakhstania, Furnishoceras, and Muensteroceras (Work \& Mason 2005) probably represents a time equivalent of the lower assemblage from the Grès de Kahla supérieur.

Belgium - The assemblages first described by de Koninck $(1844,1880)$ and later revised by Delépine (1940) from the Calcaire de Vaulx and the Calcaire de Calonne contain the genera Acrocanites, Xinjiangites, and Becanites (Calcaire de Vaulx) as well as Imitoceras, Pericyclus, Xinjiangites, Temertassetia, Jerania, Bouhamedites, and Progoniatites (Calcaire de Calonne); they have probably an earliest Late Tournaisian age.

Thuringia - Phosphatic nodules in the Rußschiefer near Zadelsdorf yielded ammonoids of the genera Gatten-

\footnotetext{
* Corresponding author
} 
dorfia, Pericyclus, Acrocanites, Xinjiangites, Stenocyclus, Progoniatites, and Becanites (?) (Schindewolf 1922, 1926, 1939). This appears to be a mixed fauna, of which at least some elements have a Late Tournaisian age.

Montagne Noire - The Horizon à Lydiennes (Lydiennes Formation) yielded a small ammonoid fauna with Globimitoceras, Gattendorfia, Goniocyclus, Nigrocyclus, and Eocanites (Böhm 1935; Korn \& Feist 2007); this fauna suggest that a Middle Tournaisian age is represented.

Kazakhstan - Librovitch (1940) described species of the genera Acutimitoceras, Paragattendorfia (?), Gattendorfia, Karagandoceras, Kazakhstania, Xinjiangites, Asiacyclus, and Eocanites from the Kassini Beds and the genera Asiacyclus, Xinjiangites, and Terektytes from the Terekty Beds. The Kassini Beds in particular yielded an assemblage similar to the Grès de Kahla supérieur.

North Xinjiang - The lower Heishantou (Donggulobasitao) Formation contains a rich ammonoid fauna with the genera Gattendorfia, Kazakhstania, Xinjiangites, Pericyclus, Zhifangoceras, Protocanites, and Becanites (Sheng 1984; Liang \& Wang 1988, 1991; Ruan 1995). Parts of this fauna are, in its genus composition, very similar to the assemblage from the Grès de Kahla supérieur.

New South Wales - Xinjiangites and Protocanites occur in the Namoi Formation together with a prionoceratid (Delépine 1941; Campbell et al. 1983). The fauna may be a time equivalent of the Grès de Kahla supérieur.

North African ammonoid faunas from the Middle and early Late Tournaisian have been described from various places:

- Area of Taouz in the Tafilalt (Anti-Atlas) - Faunas from the lower part of the Oued Znaïgui Formation yielded the genera Acutimitoceras (?), Gattendorfia, Jdaidites, Goniocyclus, and Protocanites (Korn et al. 2002, 2007); they can be attributed to the Middle Tournaisian.

- Aguelmous, Ma'der region (Anti-Atlas) - time equivalent faunas contain Globimitoceras, Goniocyclus, and Protocanites (Ebbighausen \& Bockwinkel, 2007).
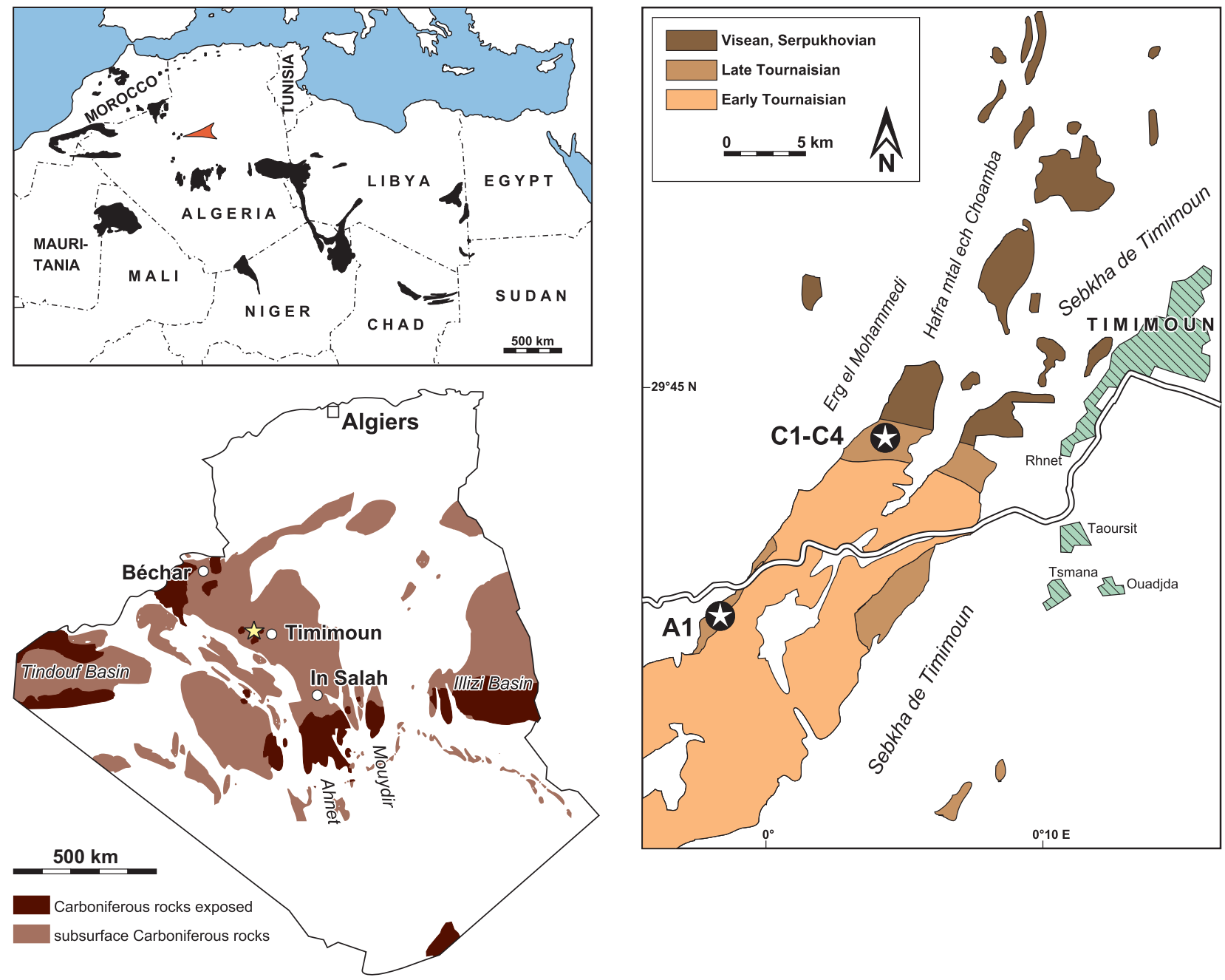

Figure 1. The outcrop of Palaeozoic rocks in northern Africa and Iberia and the geographic position (marked by an asterisk) of the fossil localities in the Grès de Kahla supérieur near Timimoun. 
- Oued Smide north of the Ma'der - another small fauna with only Gattendorfia and Acrocanites was described by Korn et al. (2007).

- Area of Taouz in the Tafilalt (Anti-Atlas) - The fauna from the middle part of the Oued Znaïgui Formation is composed of Irinoceras, Triimitoceras, Muensteroceras, Mouydiria, Ouaoufilalites, Bouhamedites, Progoniatites, Pericyclus, Helicocyclus, Jerania, and Becanites (Korn et al. 2003a). This fauna has an early Late Tournaisian age and can be interpreted as time equivalent with the younger of the here described faunas (i.e. samples TIM-A1 and TIM-C1).

- Area of Timimoun (Gourara, Algeria) - The fossiliferous section was discovered by Meyendorff (1939), who mentioned Early Tournaisian ammonoids (Ebbighausen et al. 2004). Some ammonoids from the Grès de Kahla supérieur were figured by Conrad (1984). These represent the genera Acrocanites and Becanites. New findings from this locality will be described in this article. The problematicum Duodecimedusina stella has already been described by Korn et al. (2008).

- Oued Temertasset and Hassi Habadra in the Mouydir (Algeria) - the Argiles de Teguentour are already well known for their ammonoid faunas (Termier \& Termier 1950; Follot 1953; Conrad \& Pareyn 1968; Conrad 1984). In these articles, only species of the genera Imitoceras, Pericyclus, Muensteroceras, Rotopericyclus, and Progoniatites were figured. A detailed monographic description of the fauna will be published in a parallel article (Korn et al. 2010).

\section{Geological setting}

The ammonoid faunas described here come from two localities 28 and $15 \mathrm{~km}$ west-southwest of Timimoun (Gourara, western Algeria), at the south-western margin of the Grand Erg Occidental (Figs 1, 2). Carboniferous sedimentary rocks are exposed between the sand dunes of the Grand Erg, extending over a distance of approximately $40 \mathrm{~km}$ in a SW-NE erosion window that ranges in width between a few hundreds of metres and $10 \mathrm{~km}$. The rocks are gently inclined towards the north-east. Their succession (Conrad 1984) consists mainly of shales with several intercalated sandstone formations; carbonates are very rare and restricted to distinct horizons.

The Carboniferous succession of Timimoun begins with the Grès de Kahla, a more than $300 \mathrm{~m}$ thick succession of shales with prominent sandstone intercalations, of which the lower portion at least partly has a Late Devonian age (Conrad 1984). The Grès de Kahla supérieur has a thickness of about $80 \mathrm{~m}$ and contains two major shaly portions, of which the lower one yielded a fauna of the Gattendorfia-Kahlacanites Assemblage (Ebbighausen et al. 2004; Korn et al.
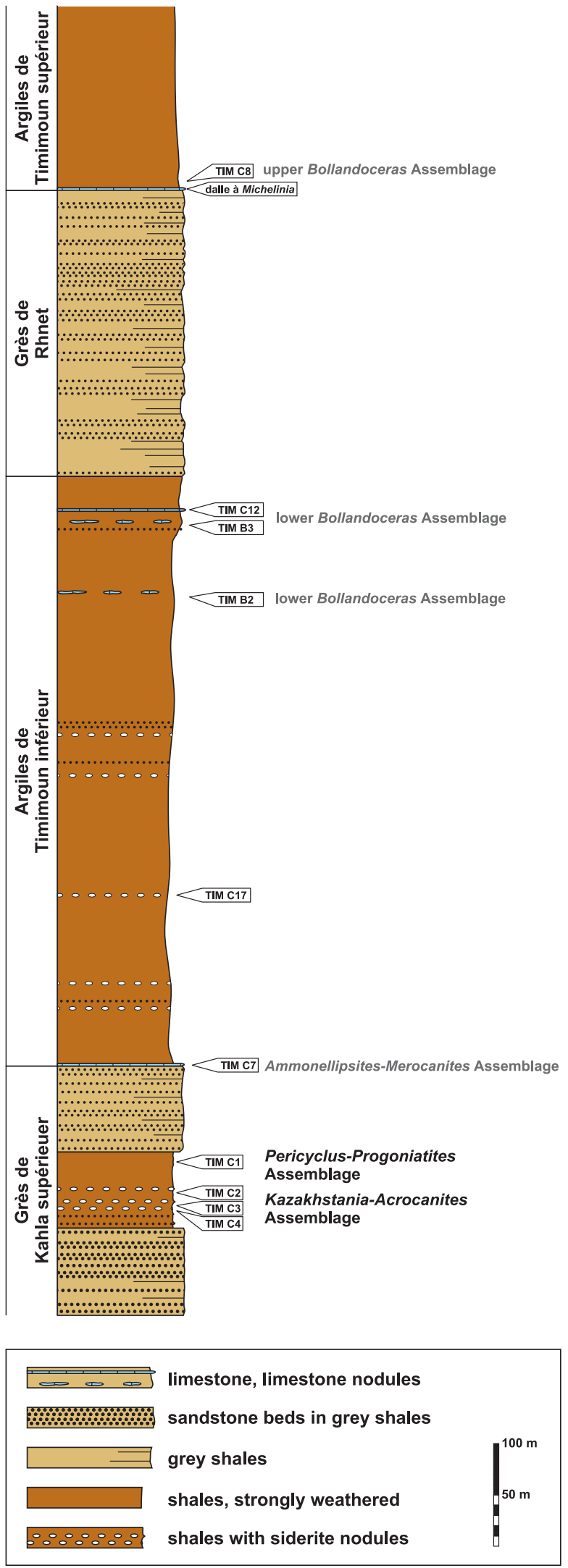

Figure 2. Stratigraphic section of the Early Carboniferous (Mississippian) rock succession near Timimoun with the position of the assemblages from the Grès de Kahla supérieur (After Ruzhencev \& Bogoslovskaya 1971; Riley 1990; Korn et al. 2004, 2007). For a description of the faunas from the Ammonellipsites-Merocanites Assemblage and Bollandoceras assemblages, see Ebbighausen et al. (2010) and Bockwinkel et al. (2010). 


\begin{tabular}{|c|c|c|c|}
\hline & chronostrat. & ammonoid genus zones & possible position of ammonoid assemblages \\
\hline \multirow{11}{*}{ 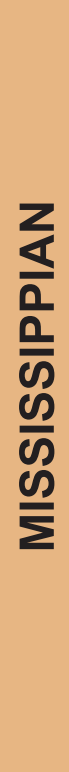 } & \multirow{2}{*}{ SERPUKHOVIAN } & Eumorphoceras - Cravenoceratoides & \multirow{11}{*}{$\begin{array}{l}\star \text { Goniatites gerberi Assemblage } \\
\star \text { Goniatites rodioni Assemblage } \\
\star \text { Goniatites tympanus Assemblage } \\
\star \text { Entogonites-Maxigoniatites Assemblage }\end{array}$} \\
\hline & & Tumulites - Cravenoceras & \\
\hline & \multirow{5}{*}{ VISÉAN } & Lusitanoceras - Lyrogoniatites & \\
\hline & & Arnsbergites - Neoglyphioceras & \\
\hline & & Goniatites - Eoglyphioceras & \\
\hline & & Entogonites & \\
\hline & & Bollandites - Bollandoceras & \\
\hline & \multirow{4}{*}{ TOURNAISIAN } & Fascipericyclus-Ammonellipsites & \\
\hline & & Pericyclus-Progoniatites & \\
\hline & & Goniocyclus-Protocanites & \\
\hline & & Gattendorfia-Eocanites & \\
\hline
\end{tabular}

Figure 3. Stratigraphic scheme of the Early Carboniferous (Mississippian) chronostratigraphy and ammonoid zonation, with correlation of the North African ammonoid assemblages (after Korn et al. 2004, 2007). Highlighted the position of the assemblages from the Grès de Kahla supérieur.

2007). In the upper of the two shaly intervals, four horizons with ammonoids were discovered, of which the lower three contain a fauna of the KazakhstaniaAcrocanites Assemblage and the upper one belongs to the Pericyclus-Progoniatites Assemblage (Fig. 3). The faunas of the higher fossiliferous horizons (Dalle à Merocanites and Argiles de Teguentour) are described in parallel (Ebbighausen et al. 2010; Bockwinkel et al. 2010).

\section{Biostratigraphy and palaeogeography}

The lower of the newly described faunas has, with its generic composition including Kazakhstania, an unquestionably position between the horizons bearing Goniocyclus and Pericyclus, and therefore, a position near the Middle-Late Tournaisian boundary is most likely. However, it cannot be stated here with certainty if this fauna has a Middle or Late Tournaisian age.
A comparable fauna with Kazakhstania, but with the endemic Furnishoceras and true Muensteroceras is known from the Borden Formation of Kentucky (Work \& Mason 2005); this was dated by conodonts as multistriatus Zone, i.e. with a position within the early Ivorian (= basal Late Tournaisian) of the Belgian chronostratigraphic scheme.

In Europe, the faunas of the Calcaire de Vaulx and Calcaire de Calonne are most similar to the assemblages described here, with the first being a time equivalent of the lower assemblage (Kazakhstania-Acrocanites Assemblage) and the latter being an equivalent of the upper assemblage (Pericyclus-Progoniatites Assemblage).

\section{Material}

At total of more than 2,900 specimens were studied from the Grès de Kahla supérieur. They come from two main localities (TIM-A and TIM$\mathrm{C}$, the latter section containing TIM-C4, TIM-C3, TIM-C2, and TIM-C1 in ascending order; Fig. 2). The material is deposited in the cephalopod collection of the Museum für Naturkunde, Berlin (MB.C. prefix).

\footnotetext{
$28 \mathrm{~km}$ west-southwest of Timimoun, locality and sample $\mathrm{TIM}^{-A 1}\left(29.1308^{\circ} \mathrm{N} ; \mathbf{0 . 0 2 1 2}^{\circ} \mathrm{W}\right)$ :

Imitoceras dimidium Korn, Bockwinkel \& Ebbighausen, 2010 Triimitoceras tantulum Korn, Bockwinkel \& Ebbighausen, 2010 Acrocanites recurvus n. sp.

Pericyclus circulus Korn, Bockwinkel \& Ebbighausen, 2010

Pericyclus trochus Korn, Bockwinkel \& Ebbighausen, 2010

Pericyclus intercisus Korn, Bockwinkel \& Ebbighausen, 2010 Ouaoufilalites creber Korn, Bockwinkel \& Ebbighausen, 2010 Temertassetia coarta Korn, Bockwinkel \& Ebbighausen, 2010 Muensteroceras subparallelum Korn, Bockwinkel \& Ebbighausen, 2010 Mouydiria scutula Korn, Bockwinkel \& Ebbighausen, 2010 9 specimens (MB.C.18638.1-9) 1 specimen (MB.C.18639) 8 specimens (MB.C.18640.1-8)

5 specimens (MB.C.18641.1-5)

37 specimens (MB.C.18642.1-37)

6 specimens (MB.C.18643.1-6)

2 specimens (MB.C.18644.1-2)

52 specimens (MB.C.18645.1-52)

322 specimens (MB.C.18646.1-322)

10 specimens (MB.C.18647.1-10)

10 specimens (MB.C.18648.1-10)
} 
Progoniatites globulus Korn, Bockwinkel \& Ebbighausen, 2010 Becanites singularis $\mathrm{n} . \mathrm{sp}$.

Becanites inflateralis $\mathrm{n}$. $\mathrm{sp}$.
12 specimens (MB.C.18649.1-12)

1 specimen (MB.C.18650)

6 specimens (MB.C.18651.1-6)

$15 \mathrm{~km}$ west-southwest of Timimoun, locality and sample $\mathrm{TIM}-\mathrm{C} 4\left(29.2264^{\circ} \mathrm{N} ; \mathbf{0 . 0 8 1 1}^{\circ} \mathrm{E}\right)$ :

Xinjiangites scalaris $\mathrm{n}$. $\mathrm{sp}$.

40 specimens (MB.C.18652.1-40)

$15 \mathrm{~km}$ west-southwest of Timimoun, locality and sample $\mathrm{TIM}^{-\mathrm{C} 3}\left(29.2264^{\circ} \mathrm{N} ; \mathrm{0.0811}^{\circ} \mathrm{E}\right)$ :

Imitoceras altilobatum $\mathrm{n}$. $\mathrm{sp}$.

8 specimens (MB.C.18653.1-8)

Triimitoceras amplisellatum $\mathrm{n}$. $\mathrm{sp}$.

Kazakhstania inequalis n. sp.

16 specimens (MB.C.18654.1-16)

656 specimens (MB.C.18655.1-656)

25 specimens (MB.C.18656.1-25)

Acrocanites imperfectus n. sp.

Xinjiangites scalaris $\mathrm{n}$. sp.

650 specimens (MB.C.18657.1-650)

Becanites canalifer $\mathrm{n}$. $\mathrm{sp}$.

3 specimens (MB.C.18658.1-3)

$15 \mathrm{~km}$ west-southwest of Timimoun, locality and sample $\mathrm{TIM}^{-\mathrm{C} 2}\left(29.2264^{\circ} \mathrm{N} ; \mathrm{0.0811}^{\circ} \mathrm{E}\right)$ :

Imitoceras altilobatum $\mathrm{n}$. $\mathrm{sp}$.

Triimitoceras amplisellatum $\mathrm{n}$. $\mathrm{sp}$.

Kazakhstania inequalis $\mathrm{n}$. sp.

Acrocanites imperfectus n. sp.

Xinjiangites scalaris $\mathrm{n}$. $\mathrm{sp}$.

Becanites canalifer $\mathrm{n}$. sp.

4 specimens (MB.C.18659.1-4)
26 specimens (MB.C.18660.1-26)
39 specimens (MB.C.18661.1-39)
274 specimens (MB.C.18662.1-274)
223 specimens (MB.C.18663.1-223)
54 specimens (MB.C.18664.1-54)

9 specimens (MB.C.18665.1-9)

3 specimens (MB.C.18666.1-3)

19 specimens (MB.C.18667.1-19)

Sample TIM-C2 + C3

Kazakhstania inequalis $\mathrm{n}$. sp.

Acrocanites imperfectus n. sp.

Xinjiangites scalaris n. sp.

$2264^{\circ} \mathrm{N} ; \mathbf{0 . 0 8 2 1}^{\circ}$ E) (Fig. 4):

$15 \mathbf{~ k m}$ west-southwest of Timimoun, locality and sample TIM
Imitoceras dimidium Korn, Bockwinkel \& Ebbighausen, 2010 Imitoceras strictum Korn, Bockwinkel \& Ebbighausen, 2010 Acrocanites recurvus n. sp.

Pericyclus tortuosus Korn, Bockwinkel \& Ebbighausen, 2010 Pericyclus circulus Korn, Bockwinkel \& Ebbighausen, 2010 Pericyclus trochus Korn, Bockwinkel \& Ebbighausen, 2010 Pericyclus intercisus Korn, Bockwinkel \& Ebbighausen, 2010 Ouaoufilalites creber Korn, Bockwinkel \& Ebbighausen, 2010 Temertassetia coarta Korn, Bockwinkel \& Ebbighausen, 2010 26 specimens (MB.C.18668.3-26)

2 specimens (MB.C.18669.1-2)

1 specimen (MB.C.18670)

1 specimen (MB.C.18671)

4 specimens (MB.C.18672.1-4)

15 specimens (MB.C.18673.1-15)

14 specimens (MB.C.18674.1-14)

1 specimen (MB.C.18675)

49 specimens (MB.C.18676.1-49)

Muensteroceras subparallelum Korn, Bockwinkel \& Ebbighausen, 2010252 specimens (MB.C.18677.1-252)

Dzhaprakoceras vergum Korn, Bockwinkel \& Ebbighausen, 2010

14 specimens (MB.C.18678.1-14)

4 specimens (MB.C.18679.1-4)

\section{Systematic Palaeontology}

The descriptive part of this monograph will mainly focus on the illustration and morphometric analysis of the

species with particular attention to their ontogenetic development. Korn (2010) published the key for the description of the species, including explanation of methods. Sutural terminology follows Korn et al. (2003b).

Order Goniatitida Hyatt, 1884

Suborder Tornoceratina Wedekind, 1914

Superfamily Prionocerataceae Hyatt, 1884

Family Prionoceratidae Hyatt, 1884

Subfamily Imitoceratinae Ruzhencev, 1950

\section{Imitoceras Schindewolf, 1923}

Type species. Ammonites rotatorius de Koninck, 1844 (original designation).

Genus definition. Imitoceratinae with large discoidal conch, reaching a conch diameter of $150 \mathrm{~mm}$. Conch subinvolute or subevolute in early juveniles; umbilicus closes completely early in ontogeny. Suture line with slightly pouched, often very narrow external lobe; ventrolateral saddle strongly asymmetric and ventrally inclined; adventive lobe strongly asymmetric and V-shaped with convex ventral flank and concave dorsal flank; adventive lobe much deeper than the external lobe.

Included species.

abundans: Imitoceras abundans Miller \& Collinson, 1951, p. 460; Missouri.

altilobatum: Imitoceras altilobatum n. sp.; Gourara (Algeria).

brevilobatum: Imitoceras brevilobatum Miller \& Collinson, 1951, p. 462; Missouri.

dimidium: Imitoceras dimidium Korn, Bockwinkel \& Ebbighausen, 2010; Mouydir (Algeria).

discoidale: Aganides discoidalis Smith, 1903, p. 13; Iowa.

indianense: Goniatites indianensis Miller, 1891, p. 90; Indiana. 


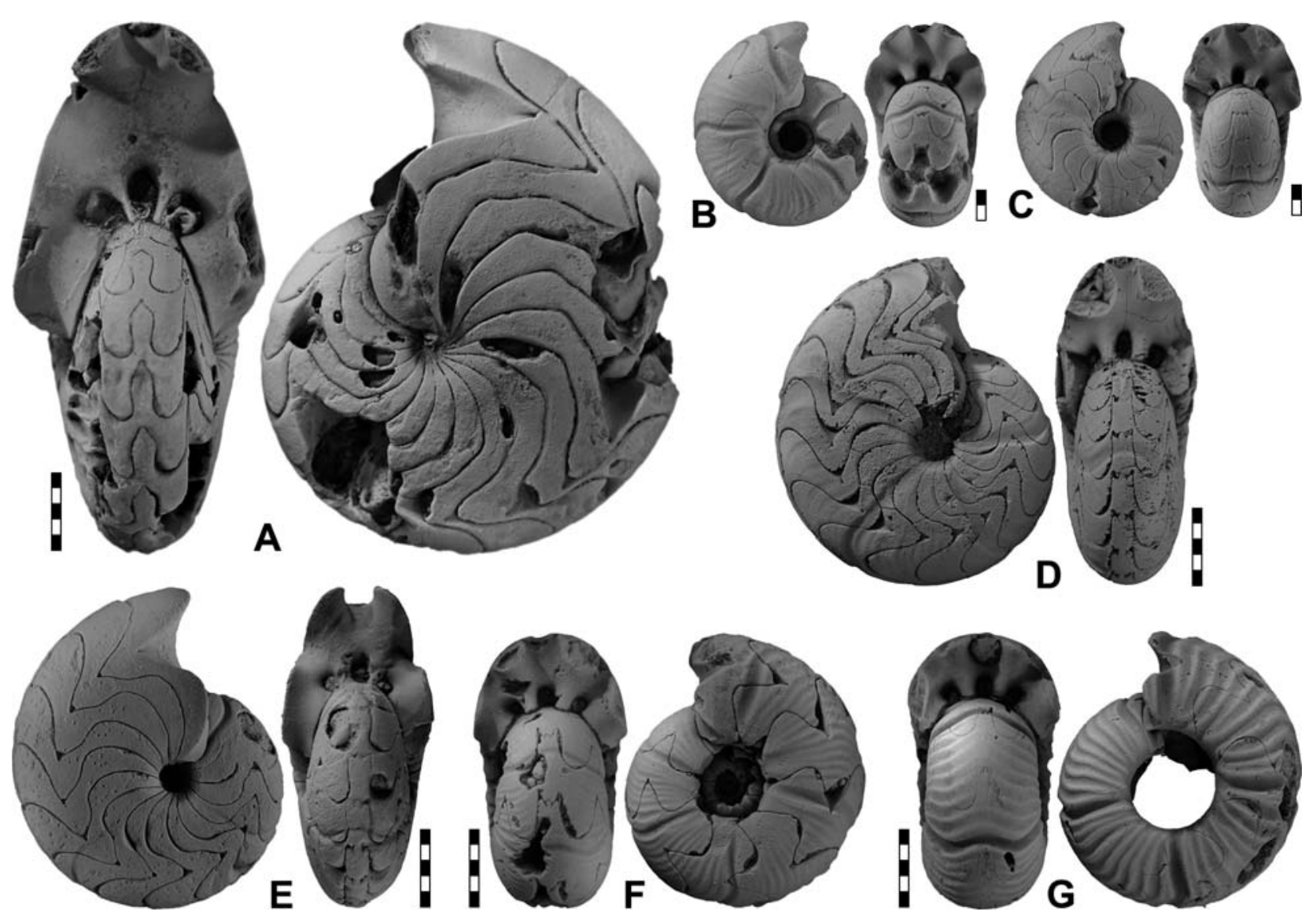

Figure 4. Selected ammonoids from locality TIM-C1; all $\times 2.0$. A. Imitoceras dimidium Korn, Bockwinkel \& Ebbighausen, 2010, specimen MB.C.18668.1. B. Temertassetia coarta Korn, Bockwinkel \& Ebbighausen, 2010, specimen MB.C.18676.2. C. Muensteroceras subparallelum Korn, Bockwinkel \& Ebbighausen, 2010, specimen MB.C.18677.2. D. Muensteroceras subparallelum Korn, Bockwinkel \& Ebbighausen, 2010, specimen MB.C.18677.1. E. Dzhaprakoceras vergum Korn, Bockwinkel \& Ebbighausen, 2010, specimen MB.C.18678.1. F. Temertassetia coarta Korn, Bockwinkel \& Ebbighausen, 2010, specimen MB.C.18676.1. G. Pericyclus intercisus Korn, Bockwinkel \& Ebbighausen, 2010, specimen MB.C.18674.1.

ixion: Goniatites Ixion Hall, 1860, p. 125; Indiana.

jessiae: Goniatites Jessiae Miller \& Gurley, 1896, p. 46; Iowa.

lentiforme: Imitoceras lentiforme Miller \& Collinson, 1951, p. 466; Missouri.

orientale: Imitoceras orientale Liang, 1976, p. 216; Tibet.

oxydentale: Imitoceras oxydentale Bockwinkel \& Ebbighausen, 2006, p. 108; Anti-Atlas.

propinquus: Goniatites propinquus Winchell, 1862, p. 365; Michigan.

rotatorium: Ammonites rotatorius de Koninck, 1844, p. 565; Belgium.

sinuatum: Aganides sinuatum Gordon, 1965, p. 166; Arkansas.

strictum: Imitoceras strictum Korn, Bockwinkel \& Ebbighausen, 2010; Mouydir (Algeria).

tardum: Imitoceras tardum Work \& Nassichuk in Work, Nassichuk \& Richards, 2000, p. 31; British Columbia.

wurmi: Imitoceras Wurmi Schindewolf, 1926, p. 71; Thuringia.

xizangense: Imitoceras xizangense Liang, 1976, p. 217; Tibet.

Discussion. Many of the species of Imitoceras require revision, and it is not clear if all the species listed above really belong to the genus. Imitoceras possesses a set of sutural characters that clearly separates it from other genera, (1) the slightly pouched external lobe, (2) the strongly asymmetric, ventrally inclined ventrolateral saddle, and (3) the asymmetric adventive lobe. Irinoceras Ruzhencev, 1947 has a much stronger pouched external lobe, and the possibly ancestral genus Nicimitoceras Korn, 1993 has a lanceolate external lobe. Triimitoceras Korn, Bockwinkel, Ebbighausen \& Klug, 2003 has a rather symmetric adventive lobe and is also distinguished from Imitoceras by its conch ontogeny with a low whorl expansion rate.

\section{Imitoceras altilobatum n. sp.}

Figures 5, 6

Derivation of name. From the Latin altus (= deep) and lobus (= lobe), because of the rather deep external lobe.

Holotype. Specimen MB.C.18659.1, illustrated in Figure 5A. 
Type locality and horizon. $15 \mathrm{~km}$ west-southwest of Timimoun, locality and sample TIM-C2 (Gourara, West Algeria); Kazakhstania-Acrocanites Assemblage.

Material. 10 specimens, conch diameter up to $18 \mathrm{~mm}$.

Diagnosis. Imitoceras with thinly globular conch in the early juvenile stage, conch width index continuously reduced during ontogeny, conch thickly discoidal at $18 \mathrm{~mm} \mathrm{dm}$; early growth stage subinvolute, closure of the umbilicus at $5 \mathrm{~mm}$ dm; aperture low in juveniles and high in adults; margin broadly rounded, flanks converging towards the broadly rounded venter. Internal mould without constrictions. Suture line with slightly pouched, moderately deep external lobe; ventrolateral saddle strongly asymmetric, ventrally inclined; adventive lobe V-shaped and asymmetric with steeper ventral side.

Table 1. Conch ontogeny (Figs 6A, C-E) of Imitoceras altilobatum n. sp.

\begin{tabular}{|c|c|c|c|}
\hline $\mathrm{dm}$ & conch shape & whorl cross section shape & aperture \\
\hline $2 \mathrm{~mm}$ & $\begin{array}{l}\text { thinly globular; subinvolute } \\
\text { (ww/dm } \sim 0.90 ; \text { uw/dm } \sim 0.18 \text { ) }\end{array}$ & $\begin{array}{l}\text { moderately depressed; very strongly embracing } \\
\text { (ww/wh } \sim 1.90 ; \text { IZR } \sim 0.52 \text { ) }\end{array}$ & $\begin{array}{l}\text { low } \\
(\text { WER } \sim 1.65)\end{array}$ \\
\hline $8 \mathrm{~mm}$ & $\begin{array}{l}\text { thinly pachyconic; involute } \\
\text { (ww/dm } \sim 0.70 ; \text { uw/dm } \sim 0.02 \text { ) }\end{array}$ & $\begin{array}{l}\text { weakly depressed; very strongly embracing } \\
\text { (ww/wh } \sim 1.15 \text {; IZR } \sim 0.50 \text { ) }\end{array}$ & $\begin{array}{l}\text { high } \\
(\text { WER } \sim 2.05)\end{array}$ \\
\hline $18 \mathrm{~mm}$ & $\begin{array}{l}\text { thickly discoidal; involute } \\
\text { (ww/dm } \sim 0.57 ; \text { uw/dm } \sim 0.02 \text { ) }\end{array}$ & $\begin{array}{l}\text { weakly compressed; very strongly embracing } \\
\text { (ww/wh } \sim 0.95 ; \text { IZR } \sim 0.46 \text { ) }\end{array}$ & $\begin{array}{l}\text { high } \\
(\text { WER 2.20) }\end{array}$ \\
\hline
\end{tabular}

Table 2. Conch dimensions (in $\mathrm{mm}$ ) and proportions for reference specimens of Imitoceras altilobatum $\mathrm{n}$. $\mathrm{sp}$.

\begin{tabular}{lrrrrrrrrrrr}
\hline & dm & ww & wh & uw & ah & ww/dm & ww/wh & uw/dm & WER & IZR & \\
\hline holotype MB.C.18659.1 & 18.0 & 10.2 & 10.8 & 0.2 & 5.8 & 0.57 & 0.95 & 0.01 & 2.18 & 0.46 \\
paratype MB.C.18653.1 & 12.9 & 8.6 & 7.9 & 0.3 & 4.3 & 0.66 & 1.08 & 0.02 & 2.23 & 0.46 \\
paratype MB.C.18659.2 & 8.8 & 6.1 & 5.4 & 0.2 & 2.7 & 0.69 & 1.13 & 0.02 & 2.10 & 0.49 \\
\hline
\end{tabular}

Table 3. Suture line proportions (Fig. 6B) for Imitoceras altilobatum n. sp.

\begin{tabular}{llllllll}
\hline specimen & at dm & EL w/d & EL/VLS & EL/AL & MS h & VLS w/h & remarks \\
\hline holotype MB.C.18659.1 & $16.5 \mathrm{~mm}$ & 0.32 & 0.53 & 0.56 & 0.00 & 0.60 & A lobe slightly deeper than E lobe \\
\hline
\end{tabular}

Discussion. Imitoceras altilobatum differs from I. dimidium from the Mouydir in the deeper external lobe, the less asymmetric adventive lobe, and in the umbilicus, which is not funnel-shaped as in A.dimidium. I. strictum possesses steinkern constrictions and is thus clearly separated from I. altilobatum. I. altilobatum is, in comparable growth stages, stouter than the other two species (ww/dm $\sim 0.60$ in I. altilobatum and only 0.50 in I. dimidium and I. strictum at $15 \mathrm{~mm} \mathrm{dm}$ ).

I. ixion and I. rotatorium possess a stronger asymmetric adventive lobe with an incurved dorsal flank, in contrast to the almost straight dorsal flank in I. altilobatum.
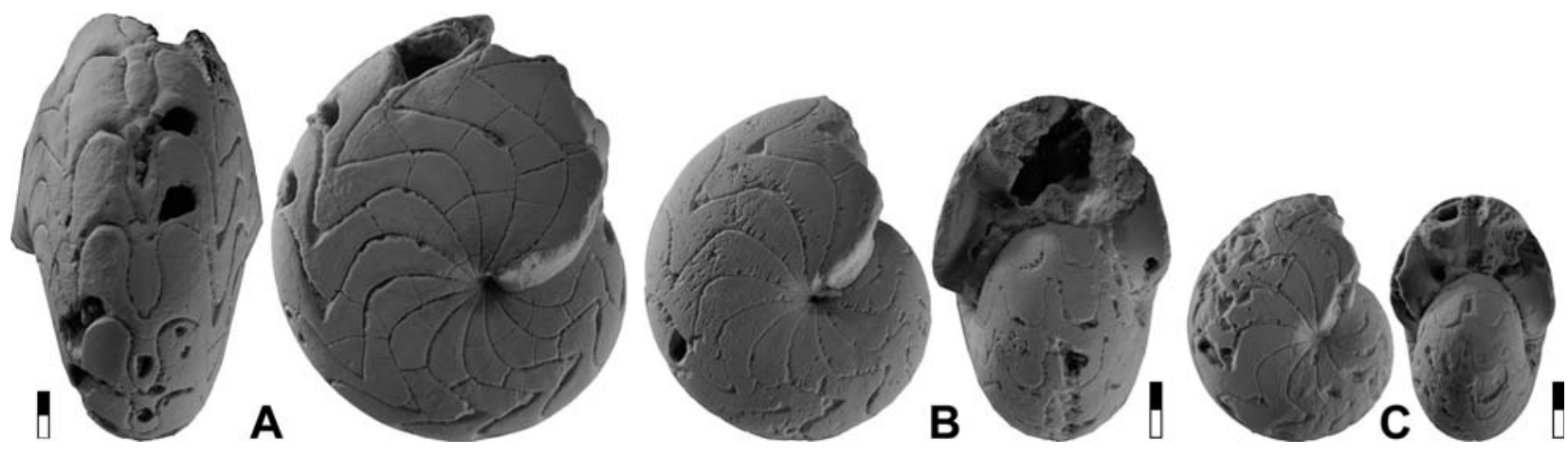

Figure 5. Imitoceras altilobatum n. sp. A. Holotype MB.C.18659.1 from locality TIM-C2; $\times 2.5$. B. Paratype MB.C.18653.1 from locality TIM-C $3 ; \times 3.0$. C. Paratype MB.C.18659.2 from locality TIM-C2; ×3.0. 

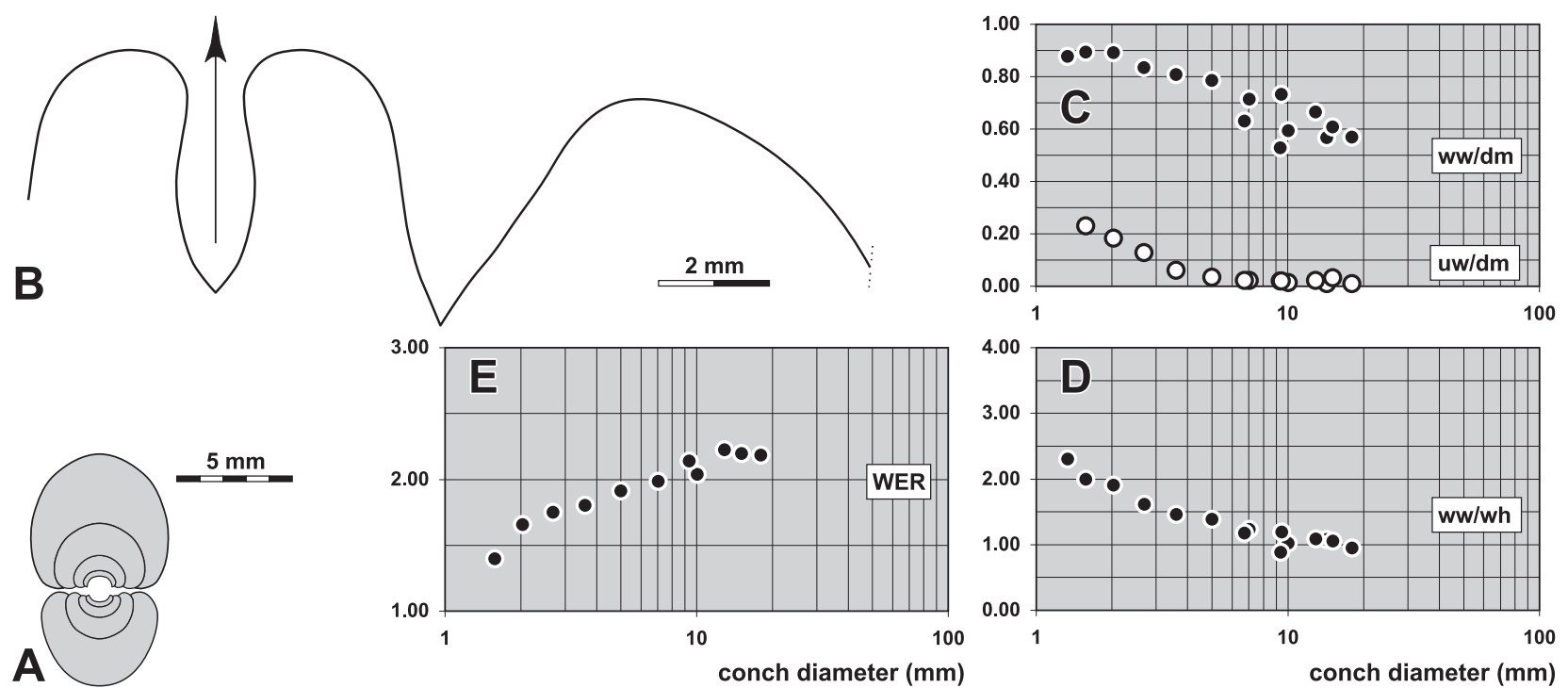

Figure 6. Imitoceras altilobatum n. sp. from locality TIM-C2. A. Cross section of paratype MB.C.18659.3; $\times 2.5$. B. Suture line of holotype MB.C.18659.1, at $16.5 \mathrm{~mm} \mathrm{dm}, 10.1 \mathrm{~mm}$ ww, $10.3 \mathrm{~mm}$ wh; $\times 6.0$. C-E. Ontogenetic development of the conch width index (ww/dm), umbilical width index (uw/dm), whorl width index (ww/wh), and whorl expansion rate (WER) of all available specimens.

\section{Triimitoceras Korn, Bockwinkel, Ebbighausen \& Klug 2003}

Type species. Triimitoceras epiwocklumeriforme Korn, Bockwinkel, Ebbighausen \& Klug 2003 (original designation).

Genus definition. Imitoceratidae with discoidal conch that is triangularly coiled in juveniles. Aperture and whorl expansion rate usually low (WER 1.50 to 1.70 ) and rarely higher in adult conchs. Suture line with slightly pouched or lanceolate external lobe and large, V-shaped adventive lobe.

Included species.

amplisellatum: Triimitoceras amplisellatum n. sp.; Gourara (Algeria).

epiwocklumeriforme: Triimitoceras epiwocklumeriforme Korn, Bockwinkel, Ebbighausen \& Klug, 2003, p. 79; Anti-Atlas (Morocco).

tantulum: Triimitoceras tantulum Korn, Bockwinkel \& Ebbighausen, 2010; Mouydir (Algeria).

Discussion. Triimitoceras has a suture line typical for the family Imitoceratinae. As in Imitoceras Schindewolf, 1923, the external lobe of the type species is slightly pouched, the ventrolateral saddle is strikingly asymmetrical, and the adventive lobe is much deeper than the external lobe. However, the conch of Triimitoceras has a much lower aperture (WER less than 1.80 in contrast to Imitoceras with more than 2.25), and the conspicuous steinkern constrictions of the type species (see below) are not known in that strength from Imitoceras. The cardinal difference, of course, is the triangular coiling of the inner whorls of Triimitoceras, not known from any other Carboniferous prionoceratid.

\section{Triimitoceras amplisellatum n. sp.}

Figures 7, 8

Derivation of name. From the Latin amplus (= wide) and sella (= saddle), because of the wide dorsolateral saddle.

Holotype. Specimen MB.C.18660.1, illustrated in Figure 7B.

Type locality and horizon. $15 \mathrm{~km}$ west-southwest of Timimoun, locality and sample TIM-C2 (Gourara, West Algeria); Kazakhstania-Acrocanites Assemblage.

Material. 43 specimens, conch diameter of up to $24 \mathrm{~mm}$.

Diagnosis. Triimitoceras with a thinly globular conch in the early juvenile stage, conch width index continuously reduced during ontogeny, conch thickly discoidal at $12 \mathrm{~mm} \mathrm{dm}$; early growth stage subinvolute, closure of the umbilicus at $5 \mathrm{~mm}$ dm; aperture low in juveniles and moderate in adults. Internal mould with concavo-convex constrictions with narrow and shallow ventral sinus; juvenile stage strongly tripartite caused by deep constrictions. Suture line with lanceolate, deep external lobe with slightly diverging flanks; ventrolateral saddle almost symmetric and broadly rounded; adventive lobe V-shaped, almost symmetric.

Discussion. Triimitoceras amplisellatum differs from T. tantulum mainly in the strongly tripartite inner whorls and in the higher aperture in comparable growth stages (WER $=1.60$ in T. tantulum but 1.95 in T. amplisellatum at $15 \mathrm{~mm} \mathrm{dm}$ ). T. epiwocklumeriforme has a pouched external lobe in the adult suture line, which is lanceolate in T. amplisellatum. 
Table 4. Conch ontogeny (Figs 8A-C, E-G) of Triimitoceras amplisellatum n. sp.

\begin{tabular}{llll}
\hline $\mathrm{dm}$ & conch shape & whorl cross section shape & aperture \\
\hline $2 \mathrm{~mm}$ & thinly globular; subinvolute & moderately depressed; very strongly embracing & low \\
& $($ ww/dm $\sim 0.90 ;$ uw/dm $\sim 0.15)$ & (ww/wh $\sim 1.90 ;$ IZR $\sim 0.60)$ & $($ WER $\sim 1.60)$ \\
$8 \mathrm{~mm}$ & thinly pachyconic; involute & weakly depressed; very strongly embracing & low to moderate \\
& $($ ww/dm $=0.65-0.70 ;$ uw $/ \mathrm{dm} \sim 0.02)$ & (ww/wh $\sim 1.20 ;$ IZR $\sim 0.58)$ & $($ WER $\sim 1.70-1.80)$ \\
$16 \mathrm{~mm}$ & thickly discoidal; involute & weakly compressed; very strongly embracing & moderate \\
& $($ ww/dm $\sim 0.50 ;$ uw/dm $\sim 0.02)$ & (ww/wh $\sim 0.90 ;$ IZR $\sim 0.50)$ & $($ WER $\sim 1.95)$
\end{tabular}

Table 5. Conch dimensions (in $\mathrm{mm}$ ) and proportions for reference specimens of Triimitoceras amplisellatum n. sp.

\begin{tabular}{lrcccccccccc}
\hline & dm & ww & wh & uw & ah & ww/dm & ww/wh & uw/dm & WER & IZR \\
\hline paratype MB.C.18660.2 & 14.4 & 7.3 & 7.4 & 0.6 & - & 0.51 & 0.99 & 0.04 & - & - \\
paratype MB.C.18660.6 & 11.1 & 6.8 & 6.2 & 0.2 & 3.1 & 0.62 & 1.10 & 0.02 & 1.93 & 0.50 \\
holotype MB.C.18660.1 & 9.0 & 5.6 & 4.7 & 0.3 & 2.5 & 0.62 & 1.19 & 0.03 & 1.89 & 0.47 \\
\hline
\end{tabular}

Table 6. Suture line proportions (Fig. 8D) for Triimitoceras amplisellatum n. sp.

\begin{tabular}{llllllll}
\hline specimen & at dm & EL w/d & EL/VLS & EL/AL & MS h & VLS w/h & remarks \\
\hline holotype MB.C.18660.1 & $7.6 \mathrm{~mm}$ & 0.36 & 0.41 & 0.68 & 0.00 & 0.88 & dorsolateral saddle very wide \\
\hline
\end{tabular}
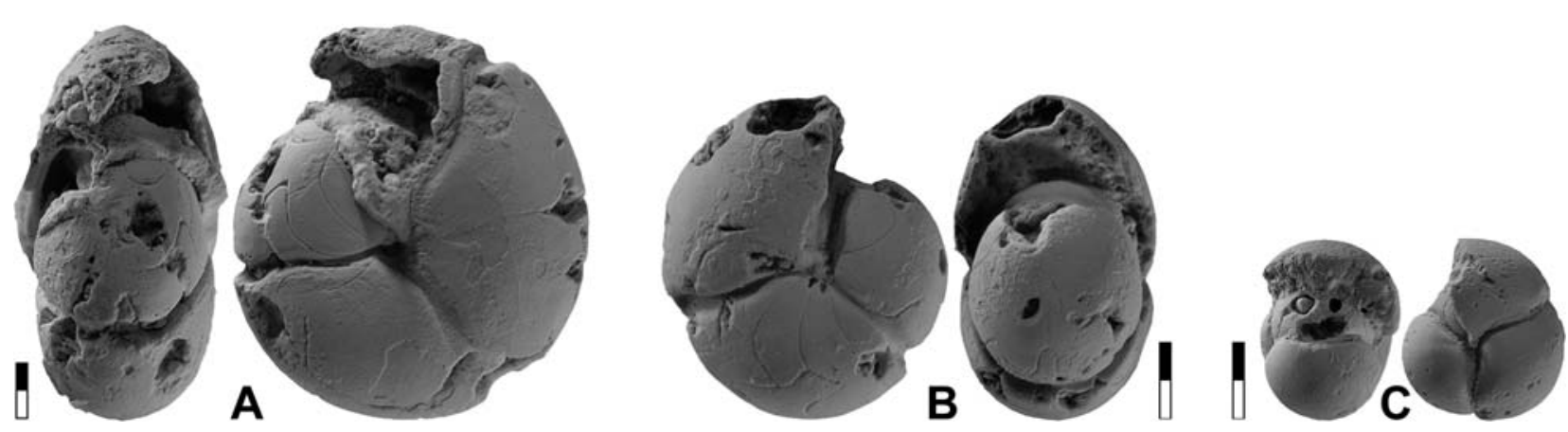

Figure 7. Triimitoceras amplisellatum n. sp. A. Paratype MB.C.18660.2 from locality TIM-C2; $\times 3.0$. B. Holotype MB.C.18660.1 from locality TIM-C2; ×4.0. C. Paratype MB.C.18654.1 from locality TIM-C3; ×4.0.
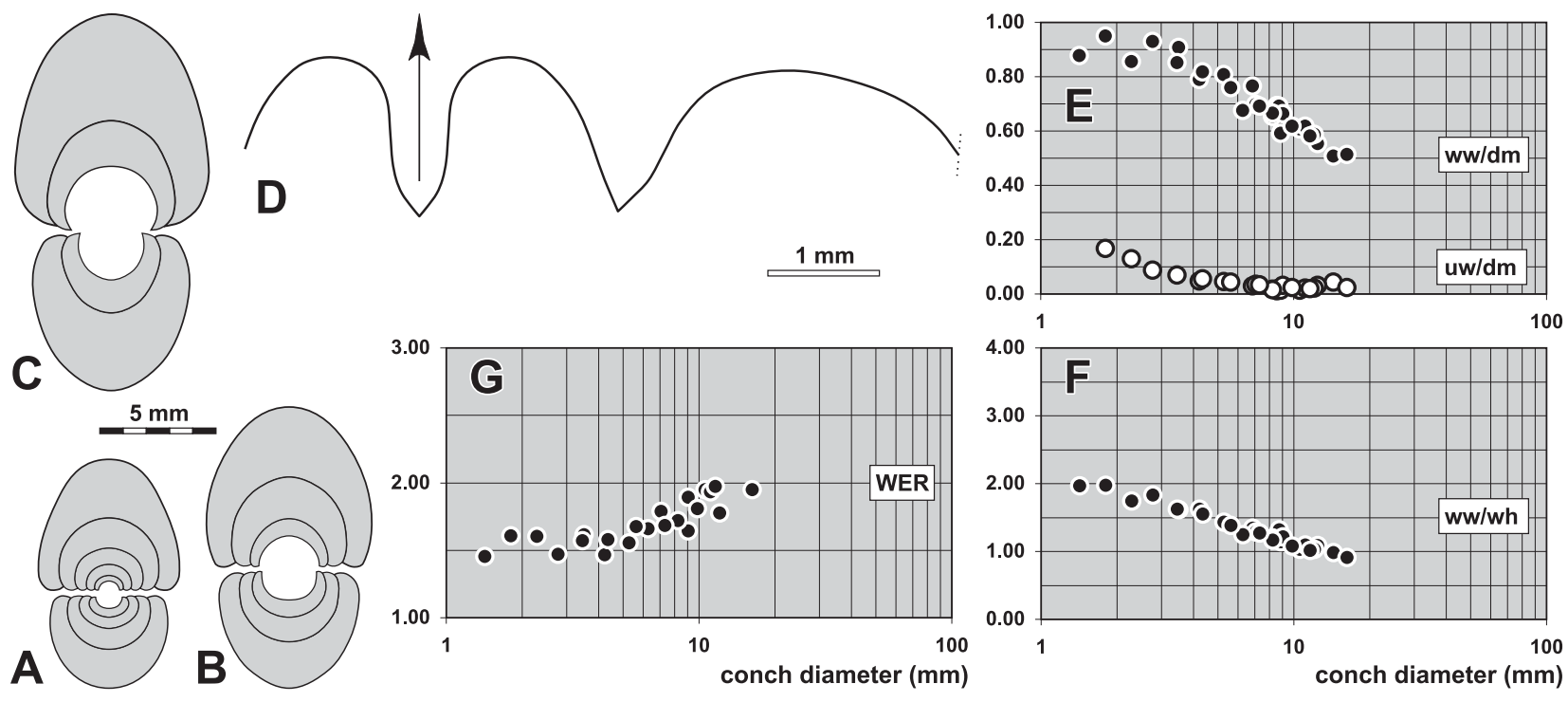

Figure 8. Triimitoceras amplisellatum n. sp. from locality TIM-C2. A. Cross section of paratype MB.C.18660.3; $\times 2.5$. B. Cross section of paratype MB.C.18660.4; $\times 2.5$. C. Cross section of paratype MB.C.18660.5; $\times 2.5$. D. Suture line of holotype MB.C.18660.1, at $7.6 \mathrm{~mm} \mathrm{dm}, 5.2 \mathrm{~mm}$ ww, $4.2 \mathrm{~mm}$ wh; $\times 12.0$. E-G. Ontogenetic development of the conch width index (ww/ $\mathrm{dm}$ ), umbilical width index (uw/dm), whorl width index (ww/wh), and whorl expansion rate (WER) of all available specimens. 
Family Gattendorfiidae Bartzsch \& Weyer, 1987

Subfamily Gattendorfiinae Bartzsch \& Weyer, 1987

\section{Kazakhstania Librovitch, 1940}

Type species. Gattendorfia (Kazakhstania) karagandaensis Librovitch, 1940 (original designation).

Genus definition. Gattendorfiidae with extremely discoidal, evolute conch, venter applanate or rounded. Suture line with deep, lanceolate and slightly pouched external lobe; adventive lobe much smaller than the external lobe, rounded or acute.

Included species.

americana: Kazakhstania americana Miller \& Garner, 1955, p. 129; Michigan.

colubrella: Ammonites colubrellus Morton, 1836, p. 154; Ohio.

compressa: Gattendorfia (Kazakhstania) compressa Ruan, 1995, p. 413; Xinjiang.

cuneata: Gattendorfia (Kazakhstania) cuneata Ruan, 1995, p. 414; Xinjiang.

depressa: Gattendorfia (Kazakhstania) depressa Librovitch, 1940, p. 72; Karaganda (Kazakhstan).

evoluta: Gattendorfia evoluta Vöhringer, 1960, p. 159; Rhenish Mountains.

inequalis: Kazakhstania inequalis n. sp.; Gourara (Algeria).

karagandaensis: Gattendorfia (Kazakhstania) karagandaensis Librovitch, 1940, p. 68; Karaganda (Kazakhstan).

mangeri: Kazakhstania mangeri Work \& Mason, 2005, p. 720; Kentucky.

mongolica: Kazakhstania mongolica Kusina in Kusina \& Lazarev, 1994, p. 165; Mongolia.

nitida: Kazakhstania nitida Bockwinkel \& Ebbighausen, 2006, p. 113; Anti-Atlas (Morocco).

umbilicata: Gattendorfia (Kazakhstania) umbilicata Ruan, 1995, p. 412; Xinjiang.

\section{Kazakhstania inequalis n. sp.}

Figures 9, 10

Derivation of name. Latin inequalis, with reference to the various shapes of sutural lobes.

Holotype. Specimen MB.C.18655.1, illustrated in Figure 9A.

Type locality and horizon. $15 \mathrm{~km}$ west-southwest of Timimoun, locality and sample TIM-C3 (Gourara, West Algeria); Kazakhstania-Acrocanites Assemblage.

Material. 704 specimens with a conch diameter up to $18 \mathrm{~mm}$

Diagnosis. Kazakhstania with thinly pachyconic conch in the earliest juvenile stage, becoming continuously slender during ontogeny and being extremely discoidal at $12 \mathrm{~mm} \mathrm{dm}$; conch evolute above $2 \mathrm{~mm}$ diameter with a slight reduction of the umbilical width in the adult stage; venter broadly rounded; aperture low in juveniles and becoming moderately high during ontogeny. Steinkern smooth except for prominent, almost linear, slightly rursiradiate constrictions. Suture line in the adult stage with very deep lanceolate external lobe (more than twice as deep as the adventive lobe), symmetrically rounded ventrolateral saddle, small and V-shaped adventive lobe and lateral lobe of the same size and shape like adventive lobe.

Table 7. Conch ontogeny (Figs 10A-D, F-H) of Kazakhstania inequalis n. sp.

\begin{tabular}{|c|c|c|c|}
\hline$d m$ & conch shape & whorl cross section shape & aperture \\
\hline $2 \mathrm{~mm}$ & $\begin{array}{l}\text { thickly discoidal; evolute } \\
\text { (ww/dm }=0.48-0.55 ; \mathrm{uw} / \mathrm{dm}=0.45-0.50 \text { ) }\end{array}$ & $\begin{array}{l}\text { moderately depressed; moderately embracing } \\
(\mathrm{ww} / \mathrm{wh}=1.65-1.85 ; \mathrm{IZR}=0.25-0.30)\end{array}$ & $\begin{array}{l}\text { Iow } \\
(\text { WER }=1.60)\end{array}$ \\
\hline $8 \mathrm{~mm}$ & $\begin{array}{l}\text { extremely or thinly discoidal; evolute } \\
\text { (ww/dm }=0.32-0.40 ; u w / d m=0.48-0.55)\end{array}$ & $\begin{array}{l}\text { weakly depressed; moderately embracing } \\
\text { (ww/wh }=1.25-1.40 ; \text { IZR }=0.15-0.20 \text { ) }\end{array}$ & $\begin{array}{l}\text { low or moderate } \\
(\text { WER }=1.70-1.80)\end{array}$ \\
\hline $20 \mathrm{~mm}$ & $\begin{array}{l}\text { extremely discoidal; evolute } \\
\text { (ww/dm }=0.30-0.35 ; \mathrm{uw} / \mathrm{dm} \sim 0.45 \text { ) }\end{array}$ & $\begin{array}{l}\text { weakly depressed; moderately embracing } \\
\text { (ww/wh }=1.00-1.15 ; \mathrm{IZR}=0.15-0.20 \text { ) }\end{array}$ & $\begin{array}{l}\text { moderate } \\
(\mathrm{WER}=1.80-2.00)\end{array}$ \\
\hline
\end{tabular}

Table 8. Conch dimensions (in $\mathrm{mm}$ ) and proportions for reference specimens of Kazakhstania inequalis $\mathrm{n}$. sp.

\begin{tabular}{|c|c|c|c|c|c|c|c|c|c|c|}
\hline & $\mathrm{dm}$ & ww & wh & uw & ah & $w w / d m$ & ww/wh & $\mathrm{uw} / \mathrm{dm}$ & WER & IZR \\
\hline holotype MB.C.18655.1 & 10.9 & 3.5 & 3.0 & 5.6 & 2.5 & 0.33 & 1.20 & 0.51 & 1.69 & 0.15 \\
\hline paratype MB.C.18655.7 & 9.1 & 3.2 & 2.5 & 4.7 & 2.2 & 0.35 & 1.26 & 0.52 & 1.72 & 0.15 \\
\hline paratype MB.C.18655.2 & 8.7 & 3.2 & 2.5 & 4.4 & 2.1 & 0.36 & 1.26 & 0.50 & 1.73 & 0.16 \\
\hline paratype MB.C.18655.8 & 7.2 & 2.8 & 1.9 & 3.9 & 1.6 & 0.38 & 1.45 & 0.54 & 1.67 & 0.15 \\
\hline
\end{tabular}

Table 9. Suture line proportions (Fig. 10E) for Kazakhstania inequalis n. sp.

\begin{tabular}{lllllll}
\hline specimen & at dm & EL w/d & EL/VLS & EL/AL & MS h & VLS w/h \\
\hline paratype MB.C.18655.7 & $8.7 \mathrm{~mm}$ & 0.36 & 0.50 & 1.05 & 0.00 & 0.72 \\
paratype MB.C.18655.2 & $7.0 \mathrm{~mm}$ & 0.30 & 0.66 & 0.85 & 0.00 & 0.46 \\
\hline
\end{tabular}


Discussion. Kazakhstania inequalis differs from the two Kazakhian species K. karagandaensis and K. depressa in the much wider external lobe and in the much stronger constrictions. The American species K. colubrella, $K$. americana, and $K$. mangeri differ in their asymmetric adventive lobe, furthermore, $K$. colubrella has a narrower umbilicus. The Chinese species have a much narrower umbilicus. Similarities in conch shape exist with the Moroccan $K$. nitida, but this species has a depressed whorl cross section.

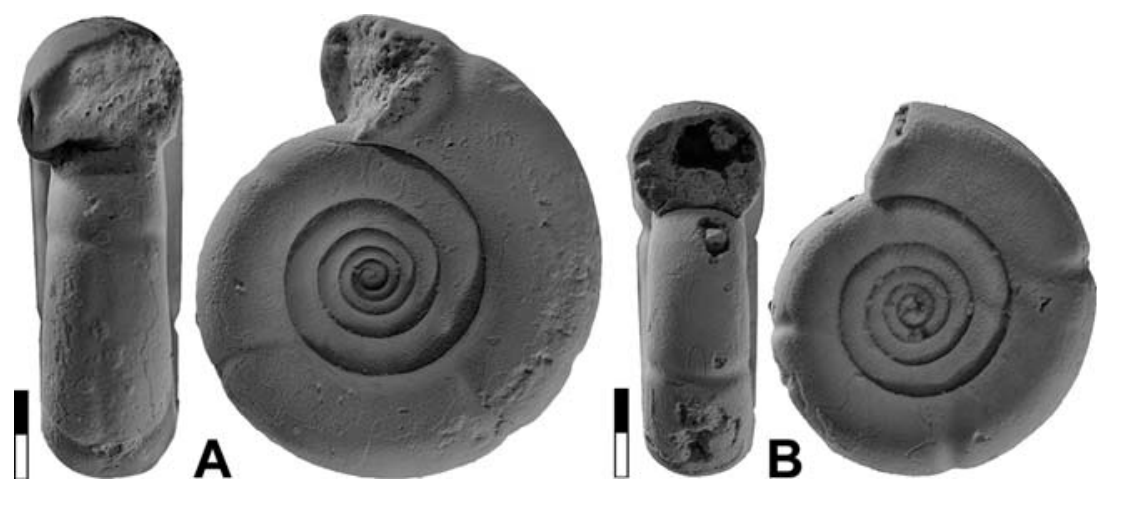

Figure 9. Kazakhstania inequalis n. sp. from locality TIM-C3; all $\times 4.0$. A. Holotype MB.C.18655.1. B. Paratype MB.C.18655.2.
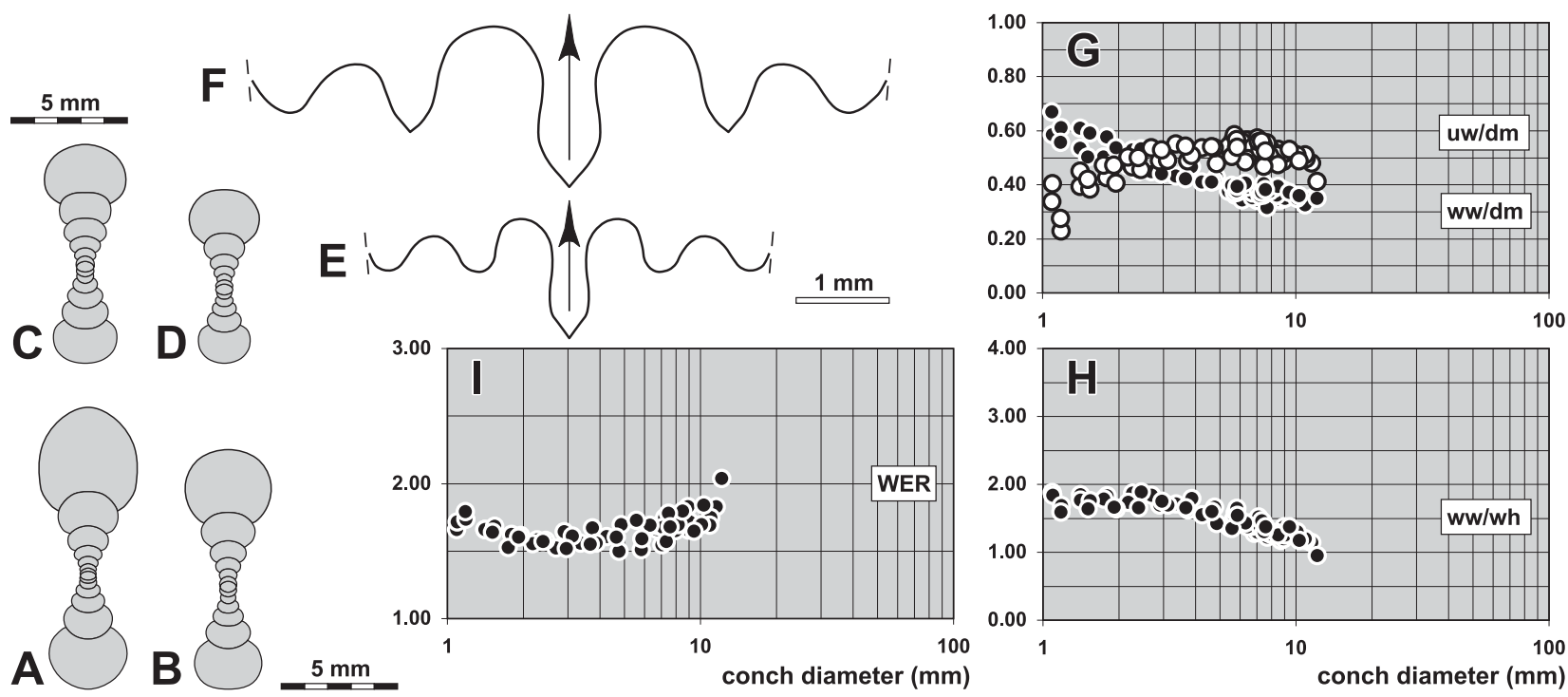

Figure 10. Kazakhstania inequalis n. sp. from locality TIM-C3. A. Cross section of paratype MB.C.18655.3; $\times 2.5$. B. Cross section of paratype MB.C.18655.4; $\times 2.5$. C. Cross section of paratype MB.C.18655.5; $\times 2.5$. D. Cross section of paratype MB.C.18655.6; $\times 2.5$. E. Suture line of paratype MB.C. 18655.2 , at $7.0 \mathrm{~mm} \mathrm{dm}, 2.7 \mathrm{~mm} \mathrm{ww}, 2.2 \mathrm{~mm} \mathrm{wh} \times 10.0$. F. Suture line of paratype MB.C.18655.7, at $8.7 \mathrm{~mm} \mathrm{dm}, 3.2 \mathrm{~mm} w w, 2.6 \mathrm{~mm}$ wh; $\times 10.0$. G-I. Ontogenetic development of the conch width index (ww/dm), umbilical width index (uw/dm), whorl width index (ww/wh), and whorl expansion rate (WER) of all available specimens.

Family Acrocanitidae Korn, Bockwinkel \& Ebbighausen, 2007

Family definition. Prionocerataceae with lenticular, evolute to almost involute conch form. Suture line multilobate with increasing number of lateral lobes.

Included genera.

Acrocanites Schindewolf, 1922

Jdaidites Korn, Bockwinkel \& Ebbighausen, 2007

\section{Acrocanites Schindewolf, 1922}

Type species. Acrocanites multilobatus Schindewolf, 1922 (original designation).

Genus definition. Acrocanitidae with extremely discoidal, subevolute or evolute conch, venter narrowly rounded in the juvenile and intermediate stage and subacute or acute in the adult stage of some species. Four to seven lobes on the flank and the umbilical wall.

Included species.

disparilis: Acrocanites disparilis Korn, Bockwinkel \& Ebbighausen, 2010; Mouydir (Algeria).

imperfectus: Acrocanites imperfectus n. sp.; Gourara (Algeria).

multilobatus: Acrocanites multilobatus Schindewolf, 1922, p. 15; Thuringia. 
recurvus: Acrocanites recurvus n. sp.; Gourara (Algeria).

smidensis: Acrocanites smidensis Korn, Bockwinkel \& Ebbighausen, 2007, p. 138; Anti-Atlas (Morocco).

tornacensis: Acrocanites tornacensis Delépine, 1940, p. 30; Belgium.

Remarks. Acrocanites has usually been placed in the order Prolecanitida. This assignment was based on the high number of lobes, as seen in advanced prolecanitids, and the pouched shape of the lobes, which are separated by inflated saddles. However, the ontogeny of the suture line displays significant differences between Acrocanites and the prolecanitids, particularly in the timing of the introduction of new lobes and their shapes. Prolecanitid ammonoids show a rapid ontogenetic unfolding of suture characters, and the full number of lobes is reached in a rather early growth stage, as Korn et al. (2003b) showed for Becanites africanus. In contrast, Acrocanites has a very slow ontogeny of sutural elements, with the full lobe number reached only in the sixth or seventh whorl. Early stages of Acrocanites have a very low adventive lobe but a lanceolate external lobe, which is twice as deep; they resemble Kazakhstania Librovitch, 1940 in this respect. Therefore, a connection of Acrocanites with the gattendorfiin ammonoids of the superfamily Prionoceratoidea is more likely than a prolecanitid origin (Korn et al. 2007).

\section{Acrocanites imperfectus n. sp.}

Figures 11, 12

Derivation of name. Lat. imperfectus, because of the relatively low number of sutural elements.

Holotype. Specimen MB.C.18662.1, illustrated in Figure 11B.

Type locality and horizon. $15 \mathrm{~km}$ west-southwest of Timimoun, locality and sample TIM-C2 (Gourara, West Algeria); Kazakhstania-Acrocanites Assemblage.

Material. 302 specimens, conch diameter up to $21 \mathrm{~mm}$.

Diagnosis. Acrocanites with thinly pachyconic conch in the earliest juvenile stage, becoming rapidly slender during early ontogeny and being extremely discoidal at $20 \mathrm{~mm} \mathrm{dm}$; conch evolute or very evolute in all stages with a slight reduction of the umbilical width in the adult stage; venter broadly rounded in juveniles and narrowly rounded in adults; aperture low or very low. Steinkern smooth. Suture line in the adult stage with slightly pouched external lobe; three pouched and acute or rounded lobes on the flank, saddles between these lobes weakly inflated; two small V-shaped and acute lobes on the umbilical wall.

Table 10. Conch ontogeny (Figs $12 \mathrm{~A}-\mathrm{D}, \mathrm{G}-\mathrm{I}$ ) of Acrocanites imperfectus n. sp.

\begin{tabular}{|c|c|c|c|}
\hline$d m$ & conch shape & whorl cross section shape & aperture \\
\hline $2 \mathrm{~mm}$ & $\begin{array}{l}\text { thinly discoidal; evolute } \\
\text { (ww/dm } \sim 0.40 ; \text { uw/dm } \sim 0.50 \text { ) }\end{array}$ & $\begin{array}{l}\text { weakly depressed; weakly or moderately embracing } \\
(\mathrm{ww} / \mathrm{wh}=1.30-1.50 ; \mathrm{IZR}=0.12-0.18)\end{array}$ & $\begin{array}{l}\text { low } \\
(\text { WER }=1.60-1.75)\end{array}$ \\
\hline $8 \mathrm{~mm}$ & $\begin{array}{l}\text { extremely discoidal; evolute or very evolute } \\
(\mathrm{ww} / \mathrm{dm}=0.28-0.32 ; \mathrm{uw} / \mathrm{dm}=0.55-0.65)\end{array}$ & $\begin{array}{l}\text { weakly depressed; moderately embracing } \\
(\mathrm{ww} / \mathrm{wh}=1.20-1.40 ; \mathrm{IZR}=0.20-0.25)\end{array}$ & $\begin{array}{l}\text { very low } \\
(\text { WER }=1.40-1.50)\end{array}$ \\
\hline $20 \mathrm{~mm}$ & $\begin{array}{l}\text { extremely discoidal; evolute } \\
\text { (ww/dm } \sim 0.25 ; \mathrm{uw} / \mathrm{dm}=0.50-0.55)\end{array}$ & $\begin{array}{l}\text { weakly compressed; moderately embracing } \\
(\mathrm{ww} / \mathrm{wh} \sim 0.90 ; \mathrm{IZR}=0.20-0.25)\end{array}$ & $\begin{array}{l}\text { low } \\
\text { (WER } \sim 1.55)\end{array}$ \\
\hline
\end{tabular}

Table 11. Conch dimensions (in $\mathrm{mm}$ ) and proportions for reference specimens of Acrocanites imperfectus n. sp.

\begin{tabular}{|c|c|c|c|c|c|c|c|c|c|c|}
\hline & $\mathrm{dm}$ & ww & wh & uw & ah & $w w / d m$ & ww/wh & $\mathrm{uw} / \mathrm{dm}$ & WER & IZR \\
\hline paratype MB.C.18662.2 & 15.9 & 4.4 & 4.0 & 8.8 & 3.4 & 0.27 & 1.08 & 0.56 & 1.61 & 0.17 \\
\hline holotype MB.C.18662.1 & 13.1 & 3.8 & 3.4 & 7.3 & 2.6 & 0.29 & 1.12 & 0.55 & 1.54 & 0.24 \\
\hline paratype MB.C.18662.3 & 12.6 & 3.4 & 2.7 & 7.5 & 2.4 & 0.27 & 1.25 & 0.59 & 1.52 & 0.13 \\
\hline
\end{tabular}

Table 12. Suture line characteristics (Figs 12E, F) for Acrocanites imperfectus n. sp.

\begin{tabular}{llllll}
\hline specimen & at dm & EL w/d & external lobe & adventive lobe & lateral lobes \\
\hline holotype MB.C.18662.1 & $12.9 \mathrm{~mm}$ & 0.47 & pouched & slightly asymmetric, rounded & 4, rounded or acute, rather wide \\
paratype MB.C.18662.3 & $12.2 \mathrm{~mm}$ & 0.35 & lanceolate & asymmetric, pointed & 3, acute and very narrow \\
\hline
\end{tabular}

Discussion. Acrocanites imperfectus differs from A. recurvus of the higher horizon of Timimoun and from $A$. disparilis from the Mouydir in the lower number of sutural elements. A. disparilis possesses five large lobes on the flank and two or three small lobes on the umbilical wall, whereas A. imperfectus shows only three large lobes on the flank and one or two small lobes on the umbilical wall. The external lobe is subparallel in A. disparilis but pouched in A. imperfectus. A. smidensis possesses only three lobes on the flank and umbilical wall and is thus clearly separated from $A$. imperfectus, which has four or five lobes. 

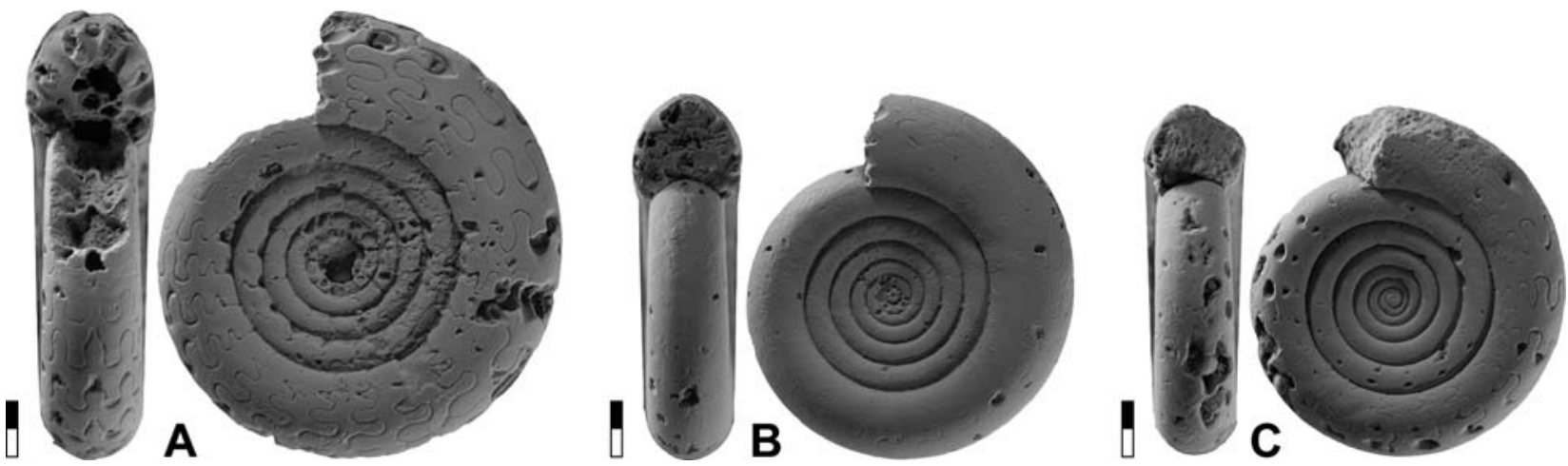

Figure 11. Acrocanites imperfectus n. sp. from locality TIM-C2; all ×3.0. A. Paratype MB.C.18662.2. B. Holotype MB.C.18662.1. C. Paratype MB.C.18662.3.

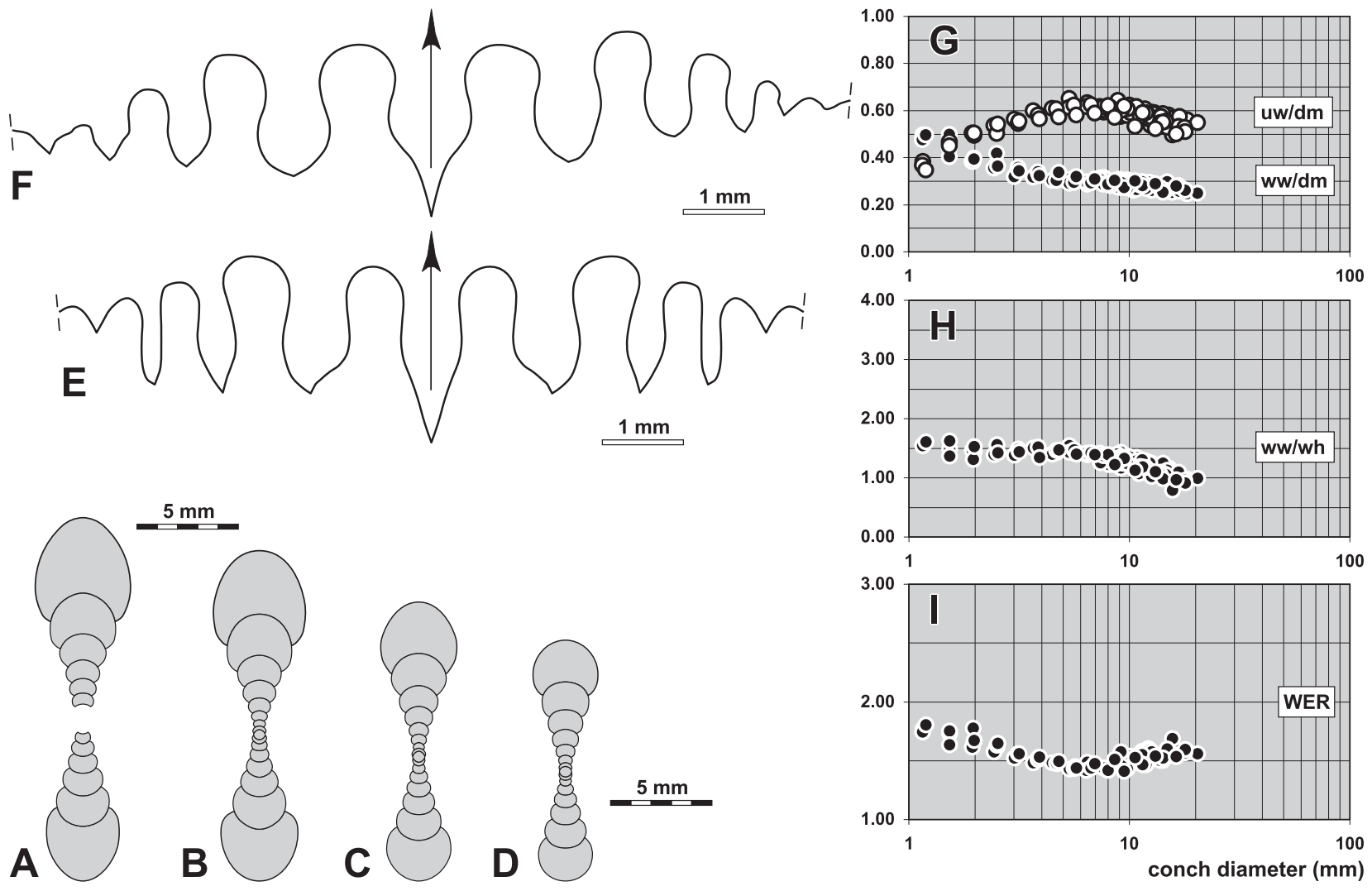

Figure 12. Acrocanites imperfectus n. sp. from locality TIM-C2. A. Cross section of paratype MB.C.18662.4; $\times 2.5$. B. Cross section of paratype MB.C.18662.5; $\times 2.5$. C. Cross section of paratype MB.C.18662.6; $\times 2.5$. D. Cross section of paratype MB.C.18662.7; $\times 2.5$. E. Suture line of paratype MB.C.18662.3, at $12.2 \mathrm{~mm} \mathrm{dm}, 3.4 \mathrm{~mm} w w, 2.8 \mathrm{~mm}$ wh; $\times 10.0$. F. Suture line of holotype MB.C.18662.1, at $12.9 \mathrm{~mm} \mathrm{dm}, 3.7 \mathrm{~mm}$ ww, $3.4 \mathrm{~mm}$ wh; $\times 10.0$. G-I. Ontogenetic development of the conch width index $(\mathrm{ww} / \mathrm{dm})$, umbilical width index (uw/dm), whorl width index (ww/wh), and whorl expansion rate (WER) of all available specimens.

\section{Acrocanites recurvus n. sp.}

Figures 13, 14

1984 Acrocanites tornacensis. - Conrad, pl. 5, figs 3-5.

Derivation of name. From the Latin recurvus (= backwardly bent), because of the suture line. Holotype. Specimen MB.C.18670, illustrated in Figure 13.

Type locality and horizon. $15 \mathrm{~km}$ west-southwest of Timimoun, locality and sample TIM-C1 (Gourara, West Algeria); Pericyclus-Progoniatites Assemblage.

Material. 9 specimens (the holotype and eight poorly preserved paratypes), conch diameter up to $24 \mathrm{~mm}$. 
Diagnosis. Acrocanites with extremely discoidal, subevolute conch at $20 \mathrm{~mm} \mathrm{dm}$; venter narrowly; aperture low. Steinkern smooth. Suture line in the adult stage with lanceolate external lobe; eight pouched and acute or rounded lobes on the flank, outer four saddles between these lobes weakly inflated; continuous size decrease of the lobes on the flank towards the umbilicus.

Discussion. Acrocanites recurvus resembles A. disparilis from the Mouydir, but differs in the slightly thicker conch (above $20 \mathrm{~mm}$ conch diameter: ww $/ \mathrm{dm}=0.25 \mathrm{in} A$. recurvus but only $0.20 \mathrm{in}$ A. disparilis) with a broader venter. The suture line of $A$. recurvus shows an almost continuous size decrease of the lobes on the flanks, whereas in A. disparilis the lobes near the umbilicus are very small.

The poorly known A. multilobatus and A.tornacensis may possess a similarly high number of lobes. The fragmentary material suggests that the umbilicus is narrower than in $A$. recurvus.

Table 13. Conch proportions of Acrocanites recurvus n. sp.

\begin{tabular}{llll}
\hline $\mathrm{dm}$ & conch shape & whorl cross section shape \\
\hline $23 \mathrm{~mm}$ & extremely discoidal; subevolute & weakly compressed; strongly embracing & aperture \\
& $($ ww/dm $\sim 0.25 ;$ uw/dm $\sim 0.43)$ & $($ ww/wh $\sim 0.75 ;$ IZR $\sim 0.33)$ & low \\
\hline
\end{tabular}

Table 14. Conch dimensions (in $\mathrm{mm}$ ) and proportions for the holotype of Acrocanites recurvus $\mathrm{n}$. sp.

\begin{tabular}{llllllllllll}
\hline & $\mathrm{dm}$ & ww & wh & uw & ah & ww/dm & ww/wh & uw/dm & WER & IZR & \\
\hline holotype MB.C.18670 & 23.3 & 5.8 & 7.7 & 9.9 & 5.2 & 0.25 & 0.75 & 0.43 & 1.66 & 0.33 & \\
\hline
\end{tabular}

Table 15. Suture line characteristics (Fig. 14) for Acrocanites recurvus n. sp.

\begin{tabular}{llllll}
\hline specimen & at dm & EL w/d & external lobe & adventive lobe & lateral lobes \\
\hline holotype MB.C.18670 & $21.9 \mathrm{~mm}$ & 0.41 & lanceolate & slightly asymmetric, acute & 7, all acute, outer three pouched \\
holotype MB.C.18670 & c. $18.0 \mathrm{~mm}$ & 0.41 & lanceolate & slightly asymmetric, acute & 6, all acute, outer two pouched \\
\hline
\end{tabular}

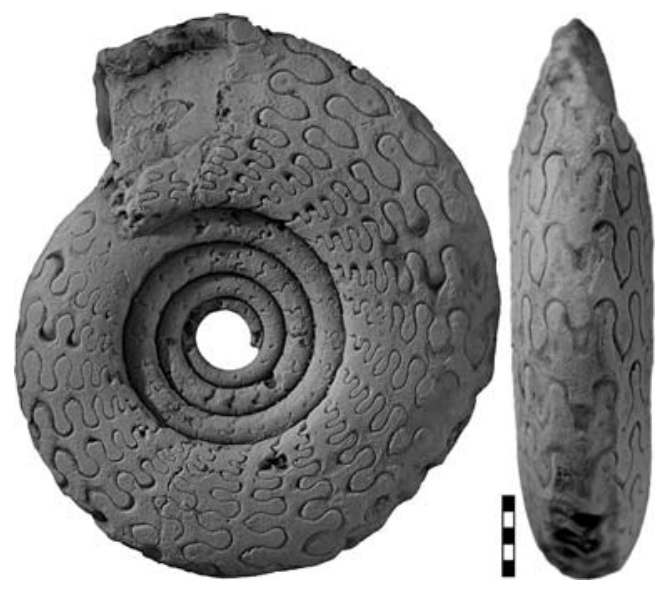

Figure 13. Acrocanites recurvus n. sp., holotype MB.C.18670 from locality TIM-C1; $\times 2.5$.

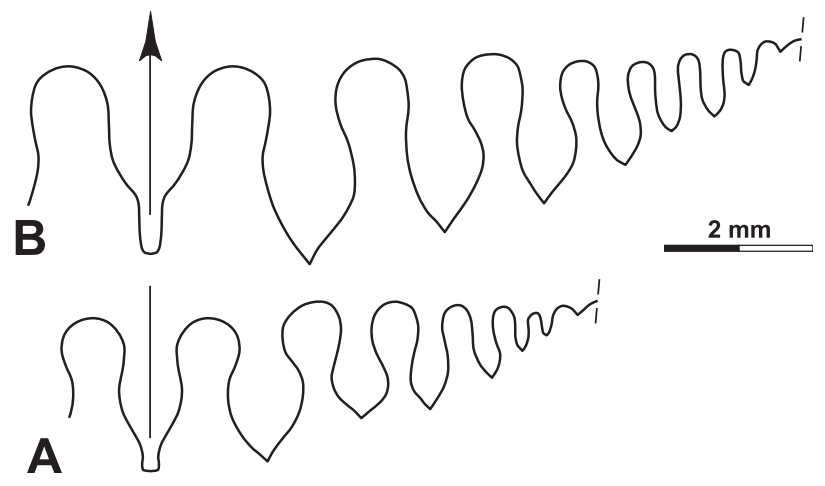

Figure 14. Acrocanites recurvus $\mathrm{n}$. $\mathrm{sp}$. from locality TIM-C1. A. Suture line of holotype MB.C.18670, at $4.7 \mathrm{~mm} \mathrm{ww}$, $4.9 \mathrm{~mm}$ wh; $\times 7.5$. B. Suture line of the same specimen, at $21.9 \mathrm{~mm} \mathrm{dm}, 5.7 \mathrm{~mm}$ ww, $7.7 \mathrm{~mm}$ wh; $\times 7.5$.

Suborder Goniatitina Hyatt, 1884

Superfamily Pericyclaceae Hyatt, 1900

Family Muensteroceratidae Librovitch, 1957

Family definition. Muensteroceratid ammonoids with usually discoidal and involute or subinvolute conch, rarely pachyconic. Suture line with subparallel-sided or parallel-sided external lobe with straight flanks (external lobe V-shaped in ancestral forms); prongs of the external lobe lanceolate; median saddle very low to moderately low.

\section{Xinjiangites Ruan, 1995}

Type species. Xinjiangites applanatus Ruan, 1995, p. 419 (original designation)

Genus definition. Muensteroceratidae with insignificant ontogenetic changes of the conch; shape pachyconic in juveniles and discoidal in the adult stage, subinvolute or involute throughout ontogeny; flanks and venter broadly rounded with compressed whorl cross section; umbilical wall 
often flattened, umbilical margin narrowly rounded or subangular. Ornament with fine, usually convex rectiradiate growth lines with rather deep ventral sinus; sometimes with shell constrictions parallel to the growth lines. Suture line with very narrow or narrow external lobe with slightly diverging flanks and very low median saddle; ventrolateral saddle broadly rounded; adventive lobe V-shaped, symmetric or slightly asymmetric.

Included species.

applanatus: Xinjiangites applanatus Ruan, 1995, p. 419; Xinjiang.

brevis: Xinjiangites brevis Ruan, 1995, p. 420; Xinjiang.

delepinei: Muensteroceras delepinei Campbell, Brown \& Coleman, 1983, p. 87; New South Wales.

medium: Munsteroceras medium Miller \& Collinson, 1951, p. 472; Missouri.

perspectivum: Goniatites perspectivus de Koninck, 1880, p. 113; Belgium.

rotella: Goniatites rotella de Koninck, 1880, p. 106; Belgium.

scalaris: Xinjiangites scalaris n. sp.; Gourara (Algeria).

Discussion. Xinjiangites differs from the other genera of the family Muensteroceratidae in its slightly diverging external lobe. It must be stated, however, that this character is rather unstable and that even specimens of the type species of Muensteroceras, M. parallelum (Hall, 1860) may show slightly diverging flanks of the external lobe. This led Ruan (1995) to the incorrect conclusion that M. koninckianum Schindewolf, 1951 (= Goniatites inconstans de Koninck, 1880) belongs to his new genus.

\section{Xinjiangites scalaris n. sp.}

Figures 15, 16

Derivation of name. After the Latin scalaris = stairway, because of the shape of the umbilicus.

Holotype. Specimen MB.C.18663.1, illustrated in Figure 15C.

Type locality and horizon. $15 \mathrm{~km}$ west-southwest of Timimoun, locality and sample TIM-C2 (Gourara, West Algeria); Kazakhstania-Acrocanites Assemblage.

Material. 932 specimens, conch diameter up to $54 \mathrm{~mm}$.

Diagnosis. Xinjiangites with thickly pachyconic conch up to $8 \mathrm{~mm} \mathrm{dm}$, thereafter continuous transformation into a thinly discoidal conch at $50 \mathrm{~mm} \mathrm{dm}$; conch subinvolute throughout ontogeny; umbilical margin subangular, umbilical wall flattened and oblique; aperture low in juveniles and moderately high above $10 \mathrm{~mm} \mathrm{dm}$. Steinkern in the adult stage smooth except for rhythmic folds, course convex with extremely deep ventral sinus. Suture line with narrow, V-shaped external lobe with gently sinuous flanks and very low median saddle; ventrolateral saddle broadly rounded and slightly asymmetric; adventive lobe V-shaped, almost symmetric with slightly curved flanks.

Table 16. Conch ontogeny (Figs 16A-C, E-G) of Xinjiangites scalaris n. sp.

\begin{tabular}{|c|c|c|c|}
\hline$d m$ & conch shape & whorl cross section shape & aperture \\
\hline $2 \mathrm{~mm}$ & $\begin{array}{l}\text { thickly pachyconic; subinvolute } \\
\text { (ww/dm } \sim 0.80 ; \text { uw/dm } \sim 0.20 \text { ) }\end{array}$ & $\begin{array}{l}\text { moderately depressed; very strongly embracing } \\
\text { (ww/wh } \sim 1.85 ; \text { IZR } \sim 0.50 \text { ) }\end{array}$ & $\begin{array}{l}\text { low } \\
\text { (WER } \sim 1.65)\end{array}$ \\
\hline $8 \mathrm{~mm}$ & $\begin{array}{l}\text { thickly pachyconic; subinvolute } \\
(\mathrm{ww} / \mathrm{dm}=0.73-0.78 ; \mathrm{uw} / \mathrm{dm}=0.20-0.30)\end{array}$ & $\begin{array}{l}\text { moderately depressed; very strongly embracing } \\
(\mathrm{ww} / \mathrm{wh}=1.70-1.80 ; \mathrm{IZR} \sim 0.48)\end{array}$ & $\begin{array}{l}\text { low } \\
\text { (WER } \sim 1.65)\end{array}$ \\
\hline $20 \mathrm{~mm}$ & $\begin{array}{l}\text { thickly discoidal; subinvolute } \\
(\mathrm{ww} / \mathrm{dm}=0.53-0.56 ; \mathrm{uw} / \mathrm{dm}=0.24-0.28)\end{array}$ & $\begin{array}{l}\text { weakly depressed; strongly embracing } \\
(\mathrm{ww} / \mathrm{wh}=1.20-1.30 ; \mathrm{IZR}=0.40-0.45)\end{array}$ & $\begin{array}{l}\text { moderate } \\
(\mathrm{WER}=1.75-1.90)\end{array}$ \\
\hline $50 \mathrm{~mm}$ & $\begin{array}{l}\text { thinly discoidal; subinvolute } \\
\text { (ww/dm } \sim 0.40 ; \text { uw/dm } \sim 0.20 \text { ) }\end{array}$ & $\begin{array}{l}\text { weakly compressed; strongly embracing } \\
\text { (ww/wh } \sim 0.85 ; \text { IZR } \sim 0.44 \text { ) }\end{array}$ & $\begin{array}{l}\text { moderate } \\
(\text { WER } \sim 1.75)\end{array}$ \\
\hline
\end{tabular}

Table 17. Conch dimensions (in $\mathrm{mm}$ ) and proportions for reference specimens of Xinjiangites scalaris n. sp.

\begin{tabular}{lccccccccccccccc}
\hline & $\mathrm{dm}$ & ww & wh & uw & ah & ww/dm & ww/wh & uw/dm & WER & IZR & & \\
\hline paratype MB.C.18657.1 & 42.1 & 18.8 & 16.8 & 9.8 & - & 0.45 & 1.12 & 0.23 & - \\
paratype MB.C.18657.2 & 37.2 & 17.2 & 16.6 & 8.7 & 9.9 & 0.46 & 1.04 & 0.23 & 1.86 & 0.40 \\
paratype MB.C.18657.6 & 25.5 & 13.1 & 11.3 & 5.9 & 6.4 & 0.51 & 1.16 & 0.23 & 1.78 & 0.43 \\
holotype MB.C.18663.1 & 19.2 & 11.3 & 8.5 & 4.1 & 4.8 & 0.59 & 1.33 & 0.21 & 1.78 & 0.44 \\
paratype MB.C.18663.2 & 13.0 & 8.6 & 5.1 & 3.1 & 3.2 & 0.66 & 1.69 & 0.24 & 1.76 & 0.37 \\
\hline
\end{tabular}

Table 18. Suture line proportions (Fig. 16D) for Xinjiangites scalaris n. sp.

\begin{tabular}{llllllll}
\hline specimen & at dm & EL w/d & EL/VLS & EL/AL & MS h & VLS w/h & remarks \\
\hline holotype MB.C.18663.1 & $18.1 \mathrm{~mm}$ & 0.51 & 0.64 & 0.72 & 0.18 & 0.80 & flanks of E lobe slightly sinuous \\
\hline
\end{tabular}


Discussion. Xinjiangites scalaris has a wider umbilicus (uw/dm $>0.20$ ) than $X$. applanatum and X. brevis from Xinjiang (uw/dm $=0.10-0.15$ ), a wider external lobe, and a higher median saddle. $X$. medium has a similar conch like $X$. scalaris, but differs in the very narrow external lobe.
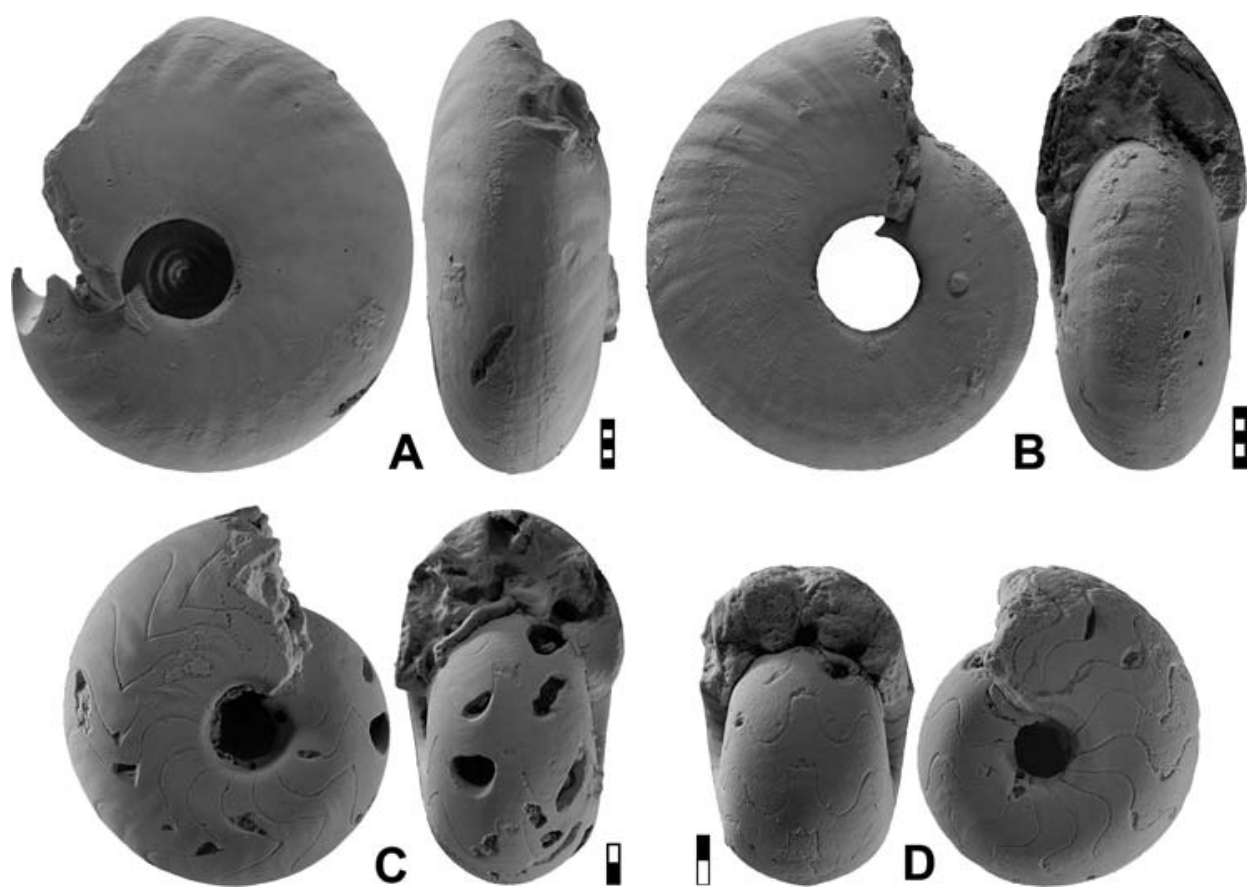

Figure 15. Xinjiangites scalaris n. sp. A. Paratype MB.C.18657.1 from locality TIM-C3; $\times 1.0$. B. Paratype MB.C.18657.2 from locality TIM-C $3 ; \times 1.25$. C. Holotype MB.C.18663.1 from locality TIM-C2; $\times 2.0$. D. Paratype MB.C.18663.2 from locality TIM-C $; \times 2.5$.

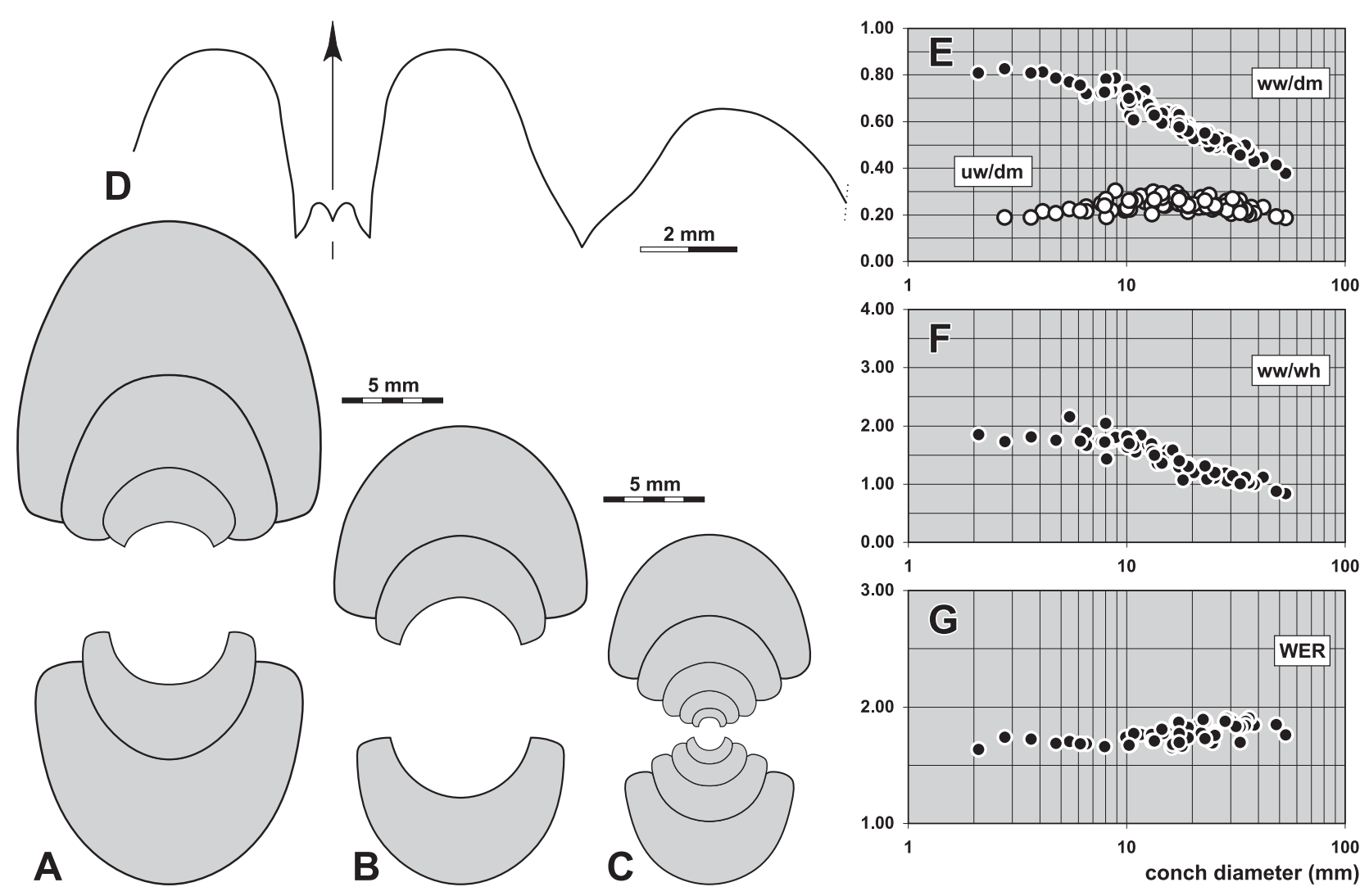

Figure 16. Xinjiangites scalaris n. sp. A. Cross section of paratype MB.C.18657.3 from locality TIM-C $3 ; \times 2.5$. B. Cross section of paratype MB.C.18657.4 from locality TIM-C3; $\times 2.5$. C. Cross section of paratype MB.C.18657.5 from locality TIM-C $3 ; \times 2.5$. D. Suture line of holotype MB.C.18663.1 from locality TIM-C2, at $18.1 \mathrm{~mm} \mathrm{dm}, 11.0 \mathrm{~mm} w w, 7.2 \mathrm{~mm}$ wh; $\times 6.0$. E-G. Ontogenetic development of the conch width index (ww/dm), umbilical width index (uw/dm), whorl width index (ww/wh), and whorl expansion rate (WER) of all available specimens. 
Order Prolecanitida Miller \& Furnish, 1954

Suborder Prolecanitina Miller \& Furnish, 1954

Superfamily Prolecanitaceae Hyatt, 1884

Family Prolecanitidae Hyatt, 1884

Subfamily Prolecanitinae Hyatt, 1884

\section{Becanites Korn, 1997}

Type species. Protocanites algarbiensis Pruvost, 1914 (original designation).

Genus definition. Prolecanitinae with a suture line consisting of external lobe, adventive lobe, lateral lobe, umbilical lobe, and internal lobe. External lobe parallel-sided or pouched, adventive lobe pouched, lateral lobe lanceolate or pouched.

Included species.

abnobensis: Protocanites supradevonicus abnobensis Vöhringer, 1960, p. 506; Black Forrest.

africanus: Becanites africanus Korn, Bockwinkel, Ebbighausen \& Klug, 2003, p. 77; Anti-Atlas.

algarbiensis: Prolecanites algarbiensis Pruvost, 1914, p. 17; South Portugal.

canalifer: Becanites canalifer n. sp.; Gourara (Algeria).

clymeniaeformis: Goniatites clymeniaeformis de Koninck, 1880, p. 95; Belgium. [Homonym of Goniatites clymeniaeformis Münster, 1839; synonym of Protocanites tornacensis Schindewolf, 1951]

geigenensis: Protocanites geigenensis Schmidt, 1924, p. 153; Franconia.

gurleyi: Prolecanites Gurleyi Smith, 1903, p. 53; Missouri.

inflateralis: Becanites inflateralis n. sp.; Mouydir (Algeria).

nuraensis: Protocanites lyoni var. nuraensis Librovitch, 1940, p. 78; Karaganda.

singularis: Becanites singularis n. sp.; Gourara (Algeria).

tornacensis: Protocanites tornacensis Schindewolf, 1951, p. 50; Belgium.

Discussion. Becanites differs from the genus Eocanites Librovitch, 1962 (in Bogoslovsky et al. 1962) in the shape of the lateral lobe, which is very small and V-shaped in Eocanites but lanceolate in Becanites. Michiganites Ruzhencev, 1962 (in Bogoslovsky et al. 1962) differs from Becanites in an additional lateral lobe.

\section{Becanites canalifer n. sp.}

Figures 17, 18

Derivation of name. From the Greek canal bearing, with reference to the ventral groove.

Holotype. Specimen MB.C.18664.1, illustrated in Figure 17B.

Type locality and horizon. $15 \mathrm{~km}$ west-southwest of Timimoun, locality and sample TIM-C2 (Gourara, West Algeria); Kazakhstania-Acrocanites Assemblage.

Material. 57 specimens, conch diameter up to $14 \mathrm{~mm}$.

Diagnosis. Becanites with thinly pachyconic conch in the earliest juvenile stage, becoming rapidly slender during early ontogeny and being extremely discoidal at $12 \mathrm{~mm} \mathrm{dm}$; conch evolute in all stages above $2 \mathrm{~mm}$ diameter with a slight increase of the umbilical width in the adult stage; whorl cross section subquadrate; venter flattened with a spiral groove; aperture moderately high. Steinkern smooth. Suture line with lanceolate, slightly pouched external lobe, broad and slightly pouched adventive lobe with subparallel flanks, and a lanceolate lateral lobe.

Table 19. Conch ontogeny (Figs $18 \mathrm{~A}-\mathrm{D}, \mathrm{F}-\mathrm{H})$ of Becanites canalifer $\mathrm{n}$. sp.

\begin{tabular}{|c|c|c|c|}
\hline$d m$ & conch shape & whorl cross section shape & aperture \\
\hline $2 \mathrm{~mm}$ & $\begin{array}{l}\text { thinly discoidal; evolute } \\
\text { (ww/dm } \sim 0.40 ; \text { uw/dm } \sim 0.45 \text { ) }\end{array}$ & $\begin{array}{l}\text { weakly depressed; weakly embracing } \\
\text { (ww/wh } \sim 1.30 ; \text { IZR } \sim 0.15 \text { ) }\end{array}$ & $\begin{array}{l}\text { moderate } \\
(\mathrm{WER} \sim 1.80)\end{array}$ \\
\hline $8 \mathrm{~mm}$ & $\begin{array}{l}\text { extremely discoidal; evolute } \\
(\mathrm{ww} / \mathrm{dm}=0.30-0.35 ; \mathrm{uw} / \mathrm{dm}=0.50-0.55)\end{array}$ & $\begin{array}{l}\text { weakly depressed; weakly embracing } \\
(\text { ww/wh }=1.10-1.20 ; \text { IZR }=0.05-0.10)\end{array}$ & $\begin{array}{l}\text { moderate } \\
(\mathrm{WER}=1.75-1.90)\end{array}$ \\
\hline $14 \mathrm{~mm}$ & $\begin{array}{l}\text { extremely discoidal; evolute } \\
\text { (ww/dm } \sim 0.32 ; \mathrm{uw} / \mathrm{dm}=0.50-0.53 \text { ) }\end{array}$ & $\begin{array}{l}\text { weakly depressed; weakly embracing } \\
\text { (ww/wh } \sim 1.20 \text {; IZR } \sim 0.05 \text { ) }\end{array}$ & $\begin{array}{l}\text { moderate } \\
(\mathrm{WER}=1.80-1.90)\end{array}$ \\
\hline
\end{tabular}

Table 20. Conch dimensions (in $\mathrm{mm}$ ) and proportions for reference specimens of Becanites canalifer $\mathrm{n}$. sp.

\begin{tabular}{|c|c|c|c|c|c|c|c|c|c|c|}
\hline & $d m$ & ww & wh & uw & ah & $w w / d m$ & ww/wh & $\mathrm{uw} / \mathrm{dm}$ & WER & IZR \\
\hline paratype MB.C.18664.2 & 13.9 & 4.3 & 3.9 & 7.4 & 3.7 & 0.31 & 1.12 & 0.53 & 1.84 & 0.06 \\
\hline holotype MB.C.18664.1 & 11.8 & 3.7 & 3.1 & 6.3 & 2.9 & 0.31 & 1.18 & 0.53 & 1.76 & 0.06 \\
\hline paratype MB.C.18664.3 & 8.6 & 2.9 & 2.5 & 4.3 & 2.3 & 0.34 & 1.17 & 0.50 & 1.85 & 0.08 \\
\hline
\end{tabular}


Table 21. Suture line proportions (Fig. 18E) for Becanites canalifer n. sp.

\begin{tabular}{llllllll}
\hline specimen & at dm & EL w/d & EL/VLS & EL/AL & MS h & VLS w/h & remarks \\
\hline holotype MB.C.18664.1 & $11.4 \mathrm{~mm}$ & 0.42 & 0.91 & 0.96 & 0.00 & 0.46 & E lobe much deeper than A lobe \\
\hline
\end{tabular}

Discussion. Becanites canalifer is the only species of the genus with a distinctive ventral groove. The subquadrate whorl cross section is a further criterion for separation of the new species; this character is only known from the insufficiently described B. geigenensis.
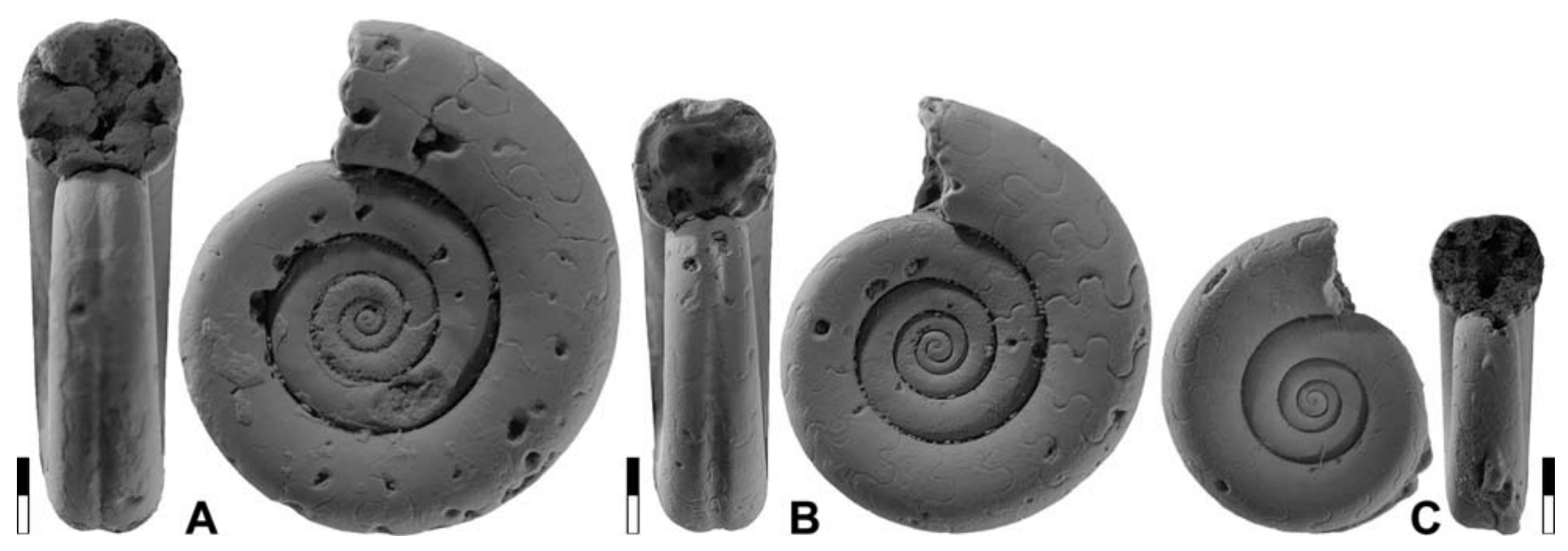

Figure 17. Becanites canalifer n. sp. from locality TIM-C2; all ×4.0. A. Paratype MB.C.18664.2. B. Holotype MB.C.18664.1. C. Paratype MB.C.18664.3.
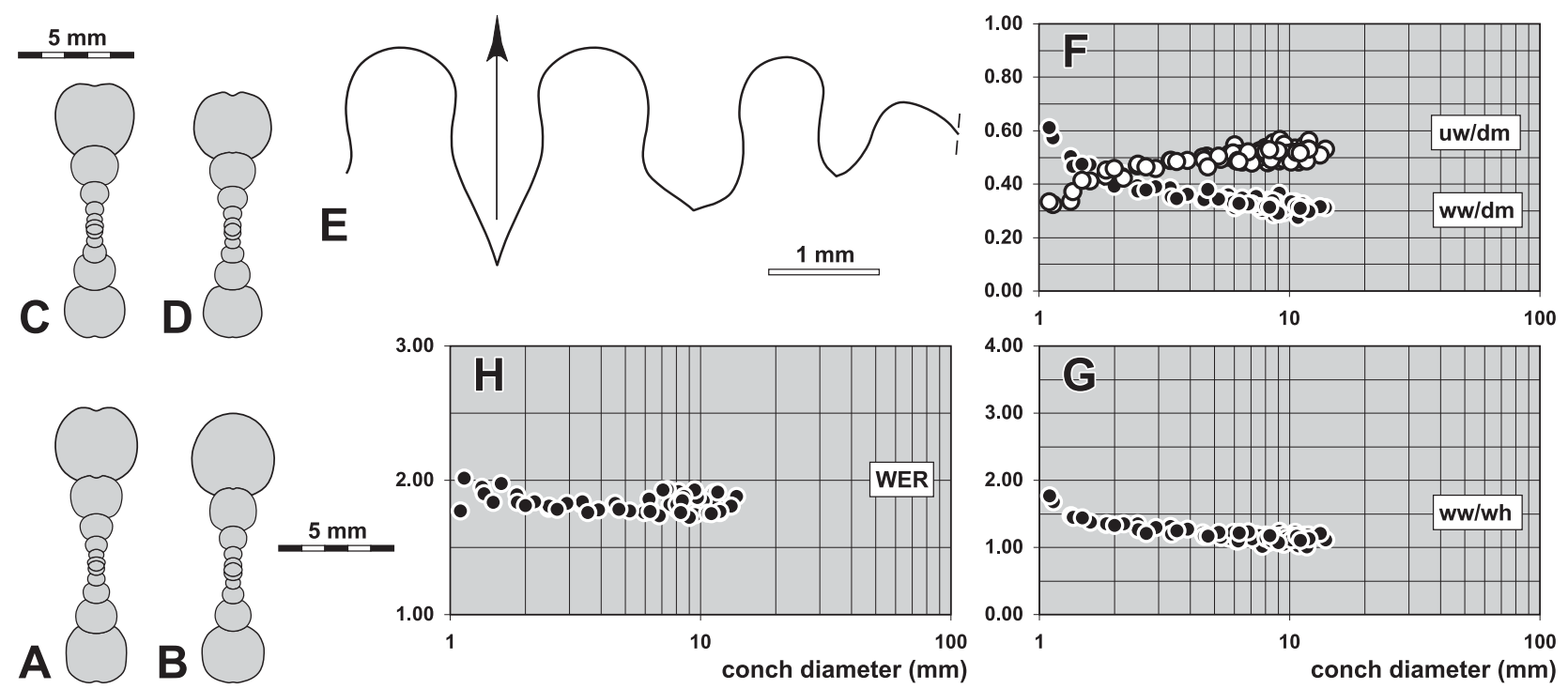

Figure 18. Becanites canalifer n. sp. from locality TIM-C2. A. Cross section of paratype MB.C.18664.4; $\times 2.5$. B. Cross section of paratype MB.C.18664.5; $\times 2.5$. C. Cross section of paratype MB.C.18664.6; $\times 2.5$. D. Cross section of paratype MB.C.18664.7; $\times 2.5$. E. Suture line of holotype MB.C.18664.1, at $11.4 \mathrm{~mm} \mathrm{dm}, 3.5 \mathrm{~mm}$ ww, $3.3 \mathrm{~mm}$ wh; $\times 12.0$. F-H. Ontogenetic development of the conch width index $(\mathrm{ww} / \mathrm{dm})$, umbilical width index (uw/dm), whorl width index (ww/wh), and whorl expansion rate (WER) of all available specimens.

\section{Becanites singularis n. sp.}

Figures 19, 20

Derivation of name. After the Latin singularis, because only one specimen is known.

Holotype. Specimen MB.C.18650, illustrated in Figure 19.

Type locality and horizon. $28 \mathrm{~km}$ west-southwest of Timimoun, locality and sample TIM-A1 (Gourara, West Algeria); Pericyclus-Progoniatites Assemblage. 
Material. Only the holotype with $15.5 \mathrm{~mm}$.

Diagnosis. Becanites with extremely discoidal, evolute conch at $15 \mathrm{~mm} \mathrm{dm}$; whorl cross section subquadrate; venter slightly flattened; aperture moderately high. Steinkern smooth. Suture line with pouched external lobe, broad and tongue-shaped adventive lobe with subparallel flanks, and a pouched lateral lobe.

Table 22. Conch proportions of Becanites singularis $\mathrm{n} . \mathrm{sp}$.

\begin{tabular}{llll}
\hline $\mathrm{dm}$ & conch shape & whorl cross section shape & aperture \\
\hline $15 \mathrm{~mm}$ & extremely discoidal; evolute & weakly depressed; weakly embracing & moderate \\
& $($ ww/dm $\sim 0.28 ;$ uw/dm $\sim 0.57)$ & $($ ww/wh $\sim 1.08 ;$ IZR $\sim 0.02)$ & $($ WER $\sim 1.80)$
\end{tabular}

Table 23. Conch dimensions (in $\mathrm{mm}$ ) and proportions for the holotype of Becanites singularis $\mathrm{n}$. $\mathrm{sp}$.

\begin{tabular}{llllllllllll}
\hline & $\mathrm{dm}$ & ww & wh & uw & ah & ww/dm & ww/wh & uw/dm & WER & IZR & \\
\hline holotype MB.C.18650 & 15.5 & 4.4 & 4.1 & 8.8 & 4.0 & 0.28 & 1.08 & 0.57 & 1.80 & 0.02 \\
\hline
\end{tabular}

Table 24. Suture line proportions (Fig. 20B) for Becanites singularis n. sp.

\begin{tabular}{llllllll}
\hline specimen & at dm & EL w/d & EL/VLS & EL/AL & MS h & VLS w/h & remarks \\
\hline holotype MB.C.18650 & $15.2 \mathrm{~mm}$ & 0.40 & 0.84 & 1.29 & 0.00 & 0.48 & A lobe as wide as the E lobe \\
\hline
\end{tabular}

Discussion. Becanites singularis differs from B. canalifer in the absence of the median groove and from B. inflateralis in the much wider umbilicus (at $15 \mathrm{~mm} \mathrm{dm:} \mathrm{uw/dm} 0.57$ in contrast to 0.45 in $B$. inflateralis) and the much lower aperture. The very wide umbilicus is a criterion to separate B. singularis from nearly all of the other species of the genus.

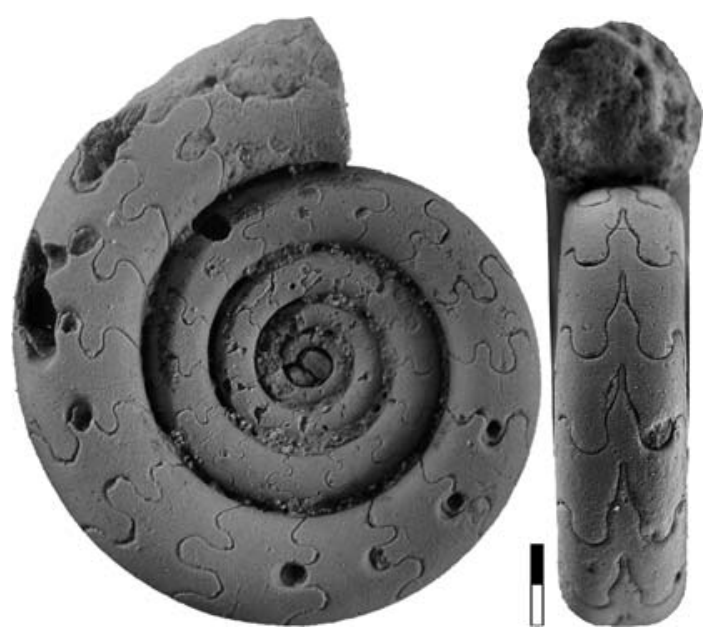

Figure 19. Becanites singularis n. sp., holotype MB.C.18650 from locality TIM-A $1 ; \times 4.0$.

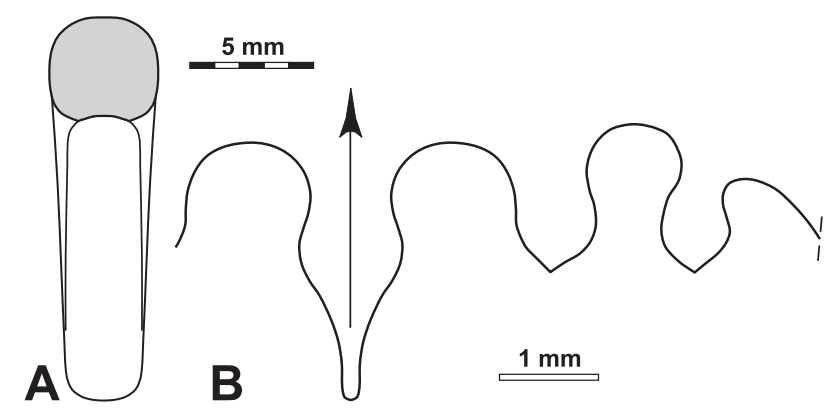

Figure 20. Becanites singularis n. sp. from locality TIM-A1. A. Dorsal view of holotype MB.C. $18650 ; \times 2.5$. B. Suture line of holotype MB.C.18650, at $15.2 \mathrm{~mm} \mathrm{dm}, 4.3 \mathrm{~mm}$ ww, $4.0 \mathrm{~mm}$ wh; $\times 10.0$.

\section{Becanites inflateralis $\mathbf{n}$. sp.}

Figures 21, 22

1984 Protocanites lyoni. - Conrad, pl. 5, fig. 6.

Derivation of name. Combination of the Latin inflatus and lateralis, because of the inflated lateral lobe. Holotype. Specimen MB.C.18679.1, illustrated in Figure 21.

Type locality and horizon. $15 \mathrm{~km}$ west-southwest of Timimoun, locality and sample TIM-C1 (Gourara, West Algeria); Pericyclus-Progoniatites Assemblage.

Material. 10 specimens, conch diameter up to $21 \mathrm{~mm}$.

Diagnosis. Becanites with extremely discoidal, subevolute conch at $20 \mathrm{~mm} \mathrm{dm}$; whorl cross section subquadrate; flanks flattened an parallel; venter slightly flattened; aperture high. Steinkern smooth. Suture line with pouched external lobe, broad and asymmetric adventive lobe with subparallel flanks, and pouched lateral lobe. 
Table 25. Conch proportions of Becanites inflateralis $\mathrm{n}$. sp.

\begin{tabular}{|c|c|c|c|}
\hline$d m$ & conch shape & whorl cross section shape & aperture \\
\hline $20 \mathrm{~mm}$ & $\begin{array}{l}\text { extremely discoidal; subevolute } \\
\text { (ww/dm } \sim 0.34 ; \mathrm{uw} / \mathrm{dm} \sim 0.43 \text { ) }\end{array}$ & $\begin{array}{l}\text { weakly depressed; weakly embracing } \\
\text { (ww/wh } \sim 1.01 ; \text { IZR } \sim 0.02 \text { ) }\end{array}$ & $\begin{array}{l}\text { high } \\
\text { (WER 2.23) }\end{array}$ \\
\hline
\end{tabular}

Table 26. Conch dimensions (in $\mathrm{mm}$ ) and proportions for the holotype of Becanites inflateralis $\mathrm{n}$. sp.

\begin{tabular}{|c|c|c|c|c|c|c|c|c|c|c|}
\hline & $\mathrm{dm}$ & ww & wh & uw & ah & $w w / d m$ & ww/wh & $\mathrm{uw} / \mathrm{dm}$ & WER & IZR \\
\hline holotype MB.C.18679.1 & 20.2 & 6.9 & 6.8 & 8.7 & 6.7 & 0.34 & 1.01 & 0.43 & 2.23 & 0.02 \\
\hline
\end{tabular}

Table 27. Suture line proportions (Fig. 22B) for Becanites inflateralis n. sp.

\begin{tabular}{llllllll}
\hline specimen & at dm & EL w/d & EL/VLS & EL/AL & MS h & VLS w/h & remarks \\
\hline holotype MB.C.18679.1 & $20.0 \mathrm{~mm}$ & 0.39 & 0.88 & 1.14 & 0.00 & 0.44 & A lobe and L lobe pouched \\
\hline
\end{tabular}

Discussion. Becanites inflateralis differs from $B$. canalifer in the absence of the median groove and from $B$. singularis in the much narrower umbilicus (at $15 \mathrm{~mm} \mathrm{dm}$ : uw/dm $\sim 0.43$ in contrast to 0.57 in $B$. singularis) and the much higher aperture. A criterion to separate $B$. inflateralis from other species is the pouched lateral lobe, which is lanceolate in most the other species of the genus. B. africanus, for instance has a much less pouched lateral lobe; additionally it has a narrower umbilicate conch.

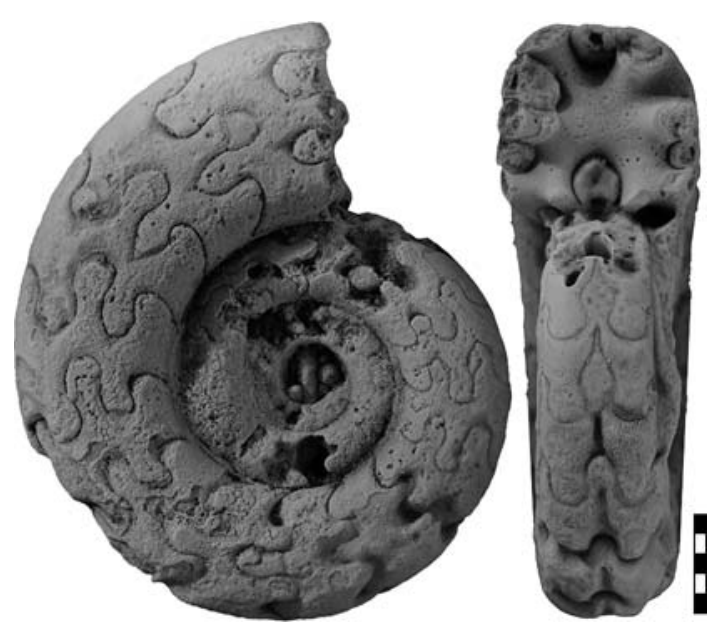

Figure 21. Becanites inflateralis n. sp., holotype MB.C.18679.1 from locality TIM-C1; $\times 3.0$.

\section{Acknowledgements}

We are indebted to the Algerian authorities for their permission for us to undertake fieldwork. D.K. acknowledges the Deutsche Forschungsgemeinschaft (DFG) for financial support (project Ko1829/3-1). Technical support was provided by Wolfgang Gerber (Tübingen) for photographing most of the specimens. We also thank Sonny Walton (Potsdam) for proofreading the manuscript and Vera Konovalova (Moscow) as well as an anonymous reviewer for a review of the article.

\section{References}

Bartzsch, K. \& Weyer, D. 1987. Die unterkarbonische AmmonoideaTribus Pseudarietitini. - Abhandlungen und Berichte für Naturkunde und Vorgeschichte 13: 59-69.

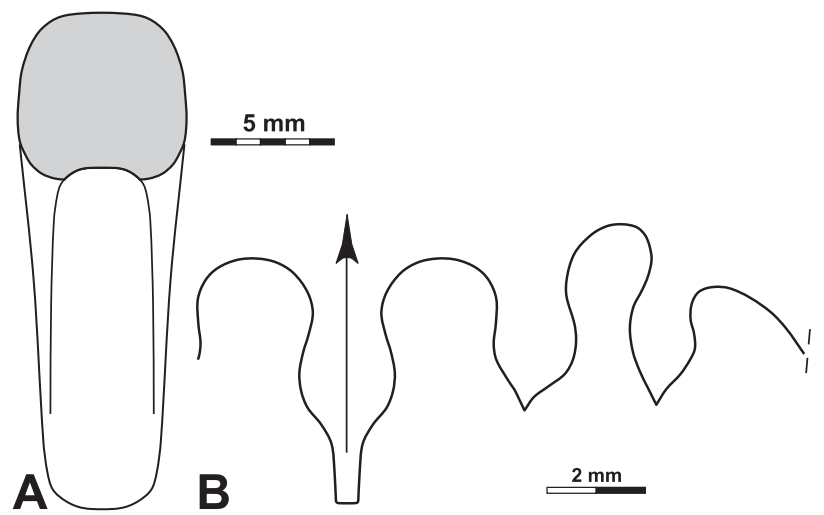

Figure 22. Becanites inflateralis n. sp. from locality TIM-C1. A. Dorsal view of holotype MB.C. $18679.1 ; \times 2.5$. B. Suture line of holotype MB.C.18679.1, at $20.0 \mathrm{~mm} \mathrm{dm}, 6.8 \mathrm{~mm} \mathrm{ww}$, $6.7 \mathrm{~mm}$ wh; $\times 5.0$.

Bockwinkel, J. \& Ebbighausen, V. 2006. A new ammonoid fauna from the Gattendorfia-Eocanites Genozone of the Anti-Atlas (Early Carboniferous, Morocco. - Fossil Record 9 (1): 87-129.

Bockwinkel, J., Korn, D. \& Ebbighausen, V. 2010. The ammonoids from the Argiles de Timimoun of Timimoun (Early and Middle Viséan; Gourara, Algeria). - Fossil Record 13 (1): 215-278.

Bogoslovsky, B. I., Librovitch, L. S. \& Ruzhencev, V. E. 1962. Nadotryad Ammonoidea. Ammonoidei. Sistematicheskaya chast. [In: Osnovy Paleontologii, Mollyuski: Golovonogie 1 (Ed. Yu. A. Orlov).] - Osnovy Paleontologii, Mollyuski - Golovonogie 1: 243425 .

Böhm, R. 1935. Études sur les faunes du Dévonien Supérieur et du Carbonifère Inférieur de la Montagne Noire. Charité, Montpellier: 203 pp.

Campbell, K. S. W., Brown, D. A. \& Coleman, A. R. 1983. Ammonoids and the correlation of the lower Carboniferous rocks of eastern Australia. - Alcheringa 7 (2): 75-123. 
Conrad, J. 1984. Les séries Carbonifères du Sahara Central Algérien stratigraphie, sédimentation, évolution structurale. Université de Droit, d'Economie et des Sciences d'Aix Marseille, Thèse de Doctorat d'Etat dès-Sciences naturelles. Marseille: $370 \mathrm{pp}$

Conrad, J. \& Pareyn, C. 1968. Présence de Goniatites cf. crenistria Phillips à la base du Viséen inférieur, dans la bassin d'Habadra (Mouydir, Sahara central). - Comptes rendus de 1'Académie des Sciences 266 (6): 569-572.

Delépine, G. 1940. Les goniatites du Dinantien de la Belgique. Mémoires du Museé Royal d'Histoire Naturelle de Belgique 91: $1-91$.

Delépine, G. 1941. Les goniatites du Carbonifère du Maroc et des confins Algéro-Marocains du sud (Dinantien-Westphalien). Notes et Mémoires, Service géologique, Protectorat de l'État Français au Maroc 56: 1-111.

Ebbighausen, V. \& Bockwinkel, J. 2007. Tournaisian (Early Carboniferous/Mississippian) ammonoids from the Ma'der Basin (Anti-Atlas, Morocco). - Fossil Record 10 (2): 125-163.

Ebbighausen, V., Bockwinkel, J., Korn, D. \& Weyer, D. 2004. Early Tournaisian ammonoids from Timimoun (Gourara, Algeria). Mitteilungen aus dem Museum für Naturkunde Berlin, Geowissenschaftliche Reihe 7: 133-152.

Ebbighausen, V., Korn, D. \& Bockwinkel, J. 2010. The ammonoids from the Dalle à Merocanites of Timimoun (Late TournaisianEarly Viséan; Gourara, Algeria). - Fossil Record 13 (1): 153-202.

Follot, J. 1953. Le Carbonifère inférieur du Sahara central. - Compte Rendue 19ième Congrès géologique international Alger, section 2 (2): 11-28.

Gordon, M. Jr. 1965. Carboniferous Cephalopods of Arkansas. - Professional Papers of the United States Geological Survey 460: 1-322.

Gutschick, R. C. \& Treckman, J. F. 1957. Lower Mississippian cephalopods from the Rockford Limestone of northern Indiana. - Journal of Paleontology 31: 1148-1153.

Hall, J. 1860. Notes and observations upon fossils of the Goniatite Limestone in the Marcellus shale of the Hamilton group, in the eastern and central parts of the State of New York, and those of the Goniatite beds of Rockford, Indiana; with some analagous forms from the Hamilton group proper. - Annual Reports of the Regents of the University of the State New York, on the condition of the State Cabinet of Natural History, and the Historical and Antiquarian Collection annexed thereto, 13: 59-112, 125.

Hyatt, A. 1883-1884. Genera of fossil cephalopods. - Proceedings of the Boston Society of Natural History 22: 253-338 (253-272 publ.1883, 273-338 publ.1884).

Hyatt, A. 1900. Tetrabranchiate Cephalopoda. In Zittel, K. v. (ed.; transl. \& ed. by C. R. Eastman). Text-book of palaeontology, volume 1, 1st edition. McMillan, New York: pp. 502-604.

Koninck, L. G. de 1844. Description des animaux fossiles qui se trouvent dans le terrain carbonifère de la Belgique. Liège, $650 \mathrm{pp}$.

Koninck, L. G. de 1880. Faune du Calcaire Carbonifère de la Belgique, deuxième partie, Genres Gyroceras, Cyrtoceras, Gomphoceras, Orthoceras, Subclymenia et Goniatites. - Annales du Musée Royal d'Histoire Naturelle de Belgique 5: 1-333.

Korn, D. 1993. The ammonoid faunal change near the Devonian-Carboniferous Boundary. - Annales de la Société Géologique de Belgique 115 (for 1992): 581-593.

Korn, D. 1997. The Palaeozoic ammonoids of the South Portuguese Zone. - Memórias do Instituto Geológico e Mineiro 33: 1-131.

Korn, D. 2010. A key for the description of Palaeozoic ammonoids. Fossil Record 13 (1): 5-12.

Korn, D., Belka, Z., Fröhlich, S., Rücklin, M. \& Wendt, J. 2004. The youngest African clymeniids (Ammonoidea, Late Devonian) failed survivors of the Hangenberg Event. - Lethaia 37: 307315.

Korn, D., Bockwinkel, J. \& Ebbighausen, V. 2007. The Tournaisian and Viséan ammonoid stratigraphy in North Africa. - Neues Jahrbuch für Geologie und Paläontologie 243 (2): 127-148.
Korn, D., Bockwinkel, J. \& Ebbighausen, V. 2010. The ammonoids from the Argiles de Teguentour of Oued Temertasset (early Late Tournaisian; Mouydir, Algeria). - Fossil Record 13 (1): 35-152.

Korn, D., Bockwinkel, J., Ebbighausen, V. \& Klug, C. 2003a. Palaeobiogeographic and evolutionary meaning of an early Late Tournaisian ammonoid fauna from the Tafilalt of Morocco. - Acta Palaeontologica Polonica 48 (1): 71-92.

Korn, D., Ebbighausen, V., Bockwinkel, J. \& Klug, C. 2003b. The Amode sutural ontogeny in prolecanitid ammonoids. - Palaeontology 46 (6): 1123-1132.

Korn, D. \& Feist, R. 2007. Early Carboniferous ammonoid faunas and stratigraphy of the Montagne Noire (France). - Fossil Record 10 (2): 99-124.

Korn, D., Klug, C., Ebbighausen, V. \& Bockwinkel, J. 2002. Palaeogeographical meaning of a Middle Tournaisian ammonoid fauna from Morocco. - Geologica at Palaeontologica 36: 79-86.

Korn, D., Weyer, D., Bockwinkel, J. \& Ebbighausen, V. 2008. Duodecimedusina stella n. sp., an Early Carboniferous (Mississippian) problematicum from Algeria. - Neues Jahrbuch frür Geologie und Paläontologie, Abhandlungen 247 (1): 9-13.

Kusina, L. F. \& Lazarev, S. S. 1994. Novye rannekamennougol'nye ammonoidei Mongolii. - Paleontologicheskiy Zhurnal 28 (1A): $157-171$.

Liang Xi-Luo 1976. Carboniferous and Permian ammonoids from the Mount Jolmo Lungma region. Ca Report on Scientific expedition in the Mount Jolmo Lungma region, 1966-1968. - Palaeontologica Sinica 3: 215-220.

Liang Xi-luo \& Wang Mingqian 1988. Carboniferous Cephalopods of Xinjiang, NW China. In Wiedmann, J. \& Kullmann, J. (eds). Cephalopods - Present and Past. Schweizerbart'sche Verlagsbuchhhandlung, Stuttgart: pp. 553-575.

Liang Xi-luo \& Wang Mingqian 1991. Carboniferous cephalopods of Xinjiang. - Paleontologica Sinica, new series B 180: 1-171.

Librovitch, L. S. 1940. Ammonoidea iz kamennougol'nykh otlozheniy Severnogo Kazakhstana [Carboniferous Ammonoids of North Kazakhstan]. - Paleontologiya SSSR 4 (9/1): VI + 392 pp.

Librovitch, L. S. 1957. O nekotorykh novykh gruppakh goniatitov iz kamennougol'nykh otlozheniy SSSR. - Ezhegodnik Vsesoyuznogo Paleontologicheskogo Obshchestva 16: 246-272.

Meyendorff, A. 1939. Les couches de passage du Dévonien au Carbonifère dans le Gourara (Sahara occidental). - Compte Rendus Hebdomadaires des Séances de l'Académie des Sciences [Paris] 209: 228-229.

Miller, A. K. \& Collinson, C. 1951. Lower Mississippian ammonoids of Missouri. - Journal of Paleontology 25: 454-487.

Miller, A. K. \& Furnish, W. M. 1954. The classification of the Paleozoic ammonoids. - Journal of Paleontology 28: 685-692.

Miller, A. K. \& Garner, H. F. 1955. Lower Mississippian cephalopods of Michigan. Part III. Ammonoids and summary. - Contributions of the Museum of Paleontology, University of Michigan 12: 113173.

Miller, S. A. 1891. Advance sheets of 17th Annual Report. - Annual Reports of the Indiana Department of Geology and Natural Resources 1892: 1-95.

Miller, S. A. \& Gurley, W. F. E. 1896. New species of Palaeozoic invertebrates from Illinois and other states. - Bulletin of the Illinois State Museum of Natural History 11: 1-50.

Münster, G. Graf zu 1839. Nachtrag zu den Goniatiten des Fichtelgebirges. - Beiträge zur Petrefactenkunde 1: 16-31.

Morton, S. G. 1836. Being a notice and description of the organic remains embraced in the preceding paper. - American Journal of Science 29: 149-154.

Pruvost, P. 1914. Observations sur les terrains Dévoniens et Carbonifères du Portugal et leur faune. - Comunicações dos Serviços Geológicos de Portugal 10: 1-22.

Ruan Yiping 1995. Tournaisian Ammonoids of Northern Xinjiang, China. - Palaeontologia Cathayana 6 (1995): 407-430. 
Riley, N. J. 1990. A global review of Mid-Dinantian ammonoid biostratigraphy. - Courier Forschungsinstitut Senckenberg 130: 133-143.

Ruzhencev, V. E. 1947. Novyy rod iz semeystva Cheiloceratidae v namyurskikh otlozheniyakh Urala. - Doklady Akademii Nauk SSSR 57 (3): 281-284.

Ruzhencev, V. E., 1950. Verkhnekamennovgolnye ammonity Urala. Trudy Paleontologicheskogo Instituta Akademiya Nauk SSSR 29: $1-220$.

Ruzhencev, V. E. \& Bogoslovskaya, M. F. 1971. Namyurskiy etap v evolyutsii ammonoidey. Rannenamyurskie ammonoidei. - Trudy Paleontologicheskogo Instituta Akademiya Nauk SSSR 133: 1-382.

Schindewolf, O. H. 1922. Über eine Unterkarbonfauna aus Ostthüringen. - Senckenbergiana 4: 8-20.

Schindewolf, O. H. 1923. Beiträge zur Kenntnis des Paläozoikums in Oberfranken, Ostthüringen und dem Sächsischen Vogtlande. I. Stratigraphie und Ammoneenfauna des Oberdevons von Hof a. S. - Neues Jahrbuch für Mineralogie, Geologie und Paläontologie, Beilage-Band 49: 250-357, 393-509.

Schindewolf, O. H. 1926. Beiträge zur Kenntnis der Cephalopodenfauna des oberfränkisch-ostthüringischen Unterkarbons. - Senckenbergiana 8: 63-96.

Schindewolf, O. H. 1939. Bemerkungen zur Stratigraphie des oberfränkisch-ostthüringischen Unterkarbons. - Jahrbuch der PreuBischen Geologischen Landesanstalt 59 (for 1938): 456-475.

Schindewolf, O.H. 1951. Über ein neues Vorkommen unterkarbonischer Pericyclus-Schichten im Oberharz. - Neues Jahrbuch für Geologie und Paläontologie, Abhandlungen 93 (1): 23-116.

Schmidt, H. 1924. Zwei Cephalopodenfaunen an der Devon-Carbongrenze im Sauerland. - Jahrbuch der Preußischen Geologischen Landesanstalt 44 (for 1923): 98-171.

Sheng Huaibin 1984. Lower Carboniferous ammonoid faunule from the Zhifang area, Xinjiang. - Acta Geologica Sinica 1984 (4): 284292.
Smith, J. P. 1903. The Carboniferous Ammonoids of America. Monographs of the United States Geological Survey 42: 1-211.

Termier, G. \& Termier, H. 1950. Paléontologie Marocaine. II. Invertébrés de l'ére Primaire. Fascicule III. Mollusques. - Notes et mémoires, Service Géologique, Protectorat de la République Française au Maroc, Direction de la Production Industrielle et des Mines, Division des Mines et de la Géologie 78: 1-246.

Vöhringer, E. 1960. Die Goniatiten der unterkarbonischen Gattendorfia-Stufe im Hönnetal (Sauerland). - Fortschritte in der Geologie von Rheinland und Westfalen 3 (1): 107-196.

Wedekind, R. 1914. Beiträge zur Kenntnis der Oberkarbonischen Goniatiten. - Mitteilungen aus dem Museum der Stadt Essen für Natur- und Völkerkunde 1: 1-22.

Winchell, A. 1862: Notice of the rocks lying between the Carboniferous limestone of the Lower Peninsula of Michigan and the limestones of the Hamilton group; with descriptions of some cephalopods supposed to be new to science. - American Journal of Science and Arts 33: 352-366.

Work, D. M. \& Mason, C. E. 2003. Mississippian (middle Osagean) ammonoids from the Nada Member of the Borden Formation, Kentucky. - Journal of Paleontology 77 (3): 593-596.

Work, D. M. \& Mason, C. E. 2004. Mississippian (late Osagean) ammonoids from the New Providence Shale Member of the Borden Formation, north-central Kentucky. - Journal of Paleontology 78 (6): 1128-1137.

Work, D. M. \& Mason, C. E. 2005. Mississippian (early Osagean) Cave Run Lake ammonoid fauna, Borden Formation, northeastern Kentucky. - Journal of Paleontology 79 (4): 719-725.

Work, D. M., Nassichuk, W. W. \& Richards, B. C. 2000. Lower Viséan ammonoids from the Lower Mount Head Formation, East-Central British Columbia. - Bulletin of the Geological Survey of Canada 541: 1-71. 